\title{
SISTEMATIZAÇÃO DA OBRA
}

Ian McReath

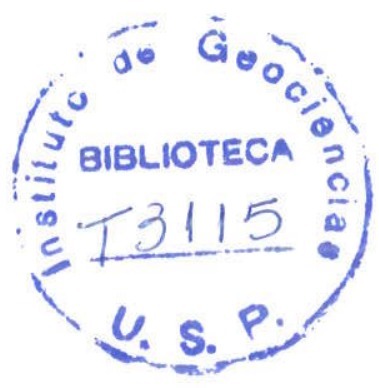

Sistematização da obra apresentada ao concurso para a obtenção do Título de Livre-Docente junto ao Departamento de Mineralogia e Geotectônica do Instituto de Geociências da Universidade de São Paulo na Área de Conhecimento Petrologia Ígnea.

SÃO PAULO 2000

DEDALUS - Acervo - IGC

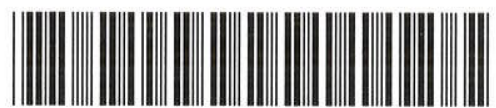

30900006693 


\section{APRESENTAÇÃO}

Em atendimento ao disposto no Edital do Diário Oficial do Estado de São Paulo, de 1 de abril de 2000, publicado pelo Instituto de Geociêncuias da Universidade de Sõ Paulo, referente à abertura de Insrição ao Concurso para a obtenção do Título de Livre-Docente junto ao Departamento de Mineralogia e Geotectônica na Área de Conhecimento Petrologia Ígnea, a presente Sistematização da Obra apresenta uma revisão crítica dos trabalhos desenvolvidos pelo candidato em duas linhas principais de pesquisa e uma lina na área correlata de Geoquímica Analítica desde seu Curso de Graduação e, principaimente, desde seu Curso de Doutoramento.

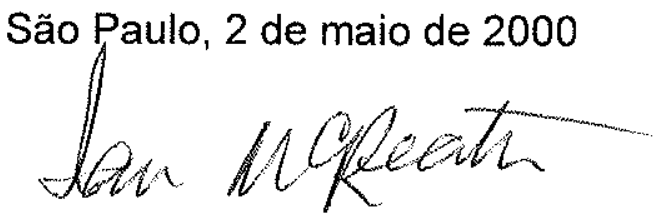

Ian McReath 


\section{IDENTIFICAÇÃO}

IAN MCREATH, inglês, filho de Kenneth Roy McReath e Kathleen Ellen McReath, nascido em 10 de setembro de 1940 em Portsmouth, Inglaterra, Reino Unido, casado com Iris Braga Pereira McReath, residente à Rua Dr. Álvaro Osório de Almeida, 245, Vila Universitária, Jardim Bonfiglioli, São Paulo, SP, portador da Cédula de Identidade de Estrangeiro RNE W254710-J, Classificação Permanente, Validade 03/02/2006, CPF No. 108.445.034/87, No. Funcional da USP 495840. 


\section{SUMÁRIO}

página

Capitulo 1

1.1 Organização da esquematização 1

$\begin{array}{ll}1.2 \text { Agradecimentos } & 2\end{array}$

Capítulo 2 Associações de rochas vulcânicas e metavulcânicas 3

2.1 Suítes recentes 3

2.2 Associações metavulcânicas proterozóicas 9

2.3 Conclusões $\quad 22$

2.4 Referências bibliográficas $\quad 23$

Apêndice 2.1 Fontes de análises de rochas vulcânicas frescas usadas no banco de dados 29

Apêndice 2.2 Análises de:

2.2.(a) komatiítos e komatítos basálticos 31

2.2.(b) picritos e ferropicritos 32

2.2.(c) boninitos 32

Referências adicionais $\quad 32$

Capítulo 3 Associações de rochas plutônicas e metaplutônicas 35

3.1 Associações máfico-ultramáficas, máficas e diferenciadas 35

3.2 Pesquisas sobre granitóides $\quad 37$

3.3 Conclusões $\quad 45$

3.4 Referências bibliográficas $\quad 46$

Capítulo 4 Análise química de rochas e minerais $\quad 50$

4.1 Comentários preliminares $\quad 50$

4.2 Verificações dos desempenhos de métodos de rotina 52

4.3 Métodos analíticos especiais $\quad 57$

4.4 Referências bibliográficas $\quad 59$ 


\section{CAPÍTULO 1: \\ ORGANIZAÇÃO DA SISTEMATIZAÇÃO; AGRADECIMENTOS}

\subsection{Organização da sistematização}

Nesta sistematização, abordam-se as atividades do candidato nas duas linhas de pesquisa principais, desenvolvidas ao longo de sua carreira, na ärea de Conhecimento Petrologia Ígnea. Incluem-se algumas observações sobre sua atuação na Área de Conhecimento correlata de Geoquímica Analítica, tendo em vista a importância que as análises quimicas das rochas tém na discussão da petrologia das rochas ígneas, e a forte ênfase que o candidato sempre dá à geoquímica das rochas..

No Capitulo 2, apresenta-se uma abordagem das pesquisas realizadas sobre rochas vulcânicas e metavulcânicas. Com respeito a estas rochas, inclui-se uma discussão dos trabalhos realizados sobre a questão da preservação ou não da composição original durante metamorfismo. Pesquisas sobre associações de rochas plutônicas e metaplutônicas são apresentadas no Capítulo 3. A ênfase dos trabalhos tem sido dada aos granitóides, e à geoquímica das rochas, o candidato acrescentou alguns aspectos da estrutura das intrusões aos seus interesses. As atividades na ärea de Geoquímica Analitica formam o assunto do Capítulo 4, salientando-se o aspecto de controle de qualidade das análises, e apresentando alguns resutados obtidos nos laboratórios do Instituto de Geociências da Universidade de São Paulo.

Informações a respeito de suas atividades em projetos isolados de pesquisa em Petrologia ĺgnea, bem como suas atividades didáticas e de formação de recursos humanas, e suas atividades na implantação de núcleos didáticos e de pesquisa encontram-se no Memorial, apresentado ao Concurso junto a esta Sistematização.

\subsection{Agradecimentos}

Correndo o risco de esquecer de um ou outro nome, o candidato gostaria de mencionar algumas pessoas cuja contribuição, de qualquer forma, ajudou na sua formaçäo. Ao Sr. W. T. Tweed, Professor de Quimica na Portsmouth Grammar School, que estimulou e treinou o candidato para participar do Concurso para Ingresso à Universidade de Oxford (Merton College); ao Prof. Dr. C. S. G. Phillips, Tutor em Química Inorgânica, cuja orientação foi fundamental na decisão do candidato de cursar 
a opção Mineralogia Suplementar; aos Prof. Drs. L. R. Wager, E. A. Vincent e J. Zussman, do Departamento de Geologia, pela sua paciência e consideração na organização da opção Mineralogia Suplementar e, subsequentemente, durante a realização do Relatório de Graduação em Química.

A seguir, ao pessoal dos Laboratórios de Química do instituto de Ciências Geológicas, Grays Inn Road, Londres, e ao Químico W. G. Heesom, do Serviço Geológico de Zâmbia, pela paciência necessária para transformar o candidato num analista sofrivel.

Aos orientadores Profs. Drs. P. G. Harris e P. E. Baker, aos técnicos do Laboratório de Espectrometria de Fluorescência de Raios-X, T. Padfield e A. Grey e à a Prof ${ }^{a}$. Dr ${ }^{a}$. J. M. Rooke e o técnico A. Richardson do Laboratório de Espectrografia Optica, ao Sr. F. Buckley, do Laboratorio de Análise Quimica, e aos técnicos do Laboratório de Geocronologia D. C. Rex e A. Gledhill pela sua instrução nas suas respectivas áreas, e pela ajuda e incentivação no desenvolvimento da Tese de Doutorado; para os colegas de Pós Graduação J. Hallas e T. Marshall pela colaboração nas pesquisas sobre as ilhas de Tofua e Kao, Tonga.

No Brasil, aos Profs. Drs. R. L. Bartels, B. J. Fryer e P. Siems, pelo companheirismo nas fases iniciais da estadia no Brasil; a dois dos primeiros alunos do Curso de Pós Graduação em Geoquímica da UFBA, E. F. J. de Sá e M. C. H. Figueiredo, pelo estímulo para sempre oferecer matéria interessante nas disciplinas de geoquímica; aos Profs. Drs. P. Sabaté e I. Davison, pelo ensino de elementos de geologia estrutural; ao Prof. Dr. A. N. Sial, co-autor do livro texto, e ao Geol. H. A. V. Inda, editor, pelo estímulo (e pelos empurrões) para terminar a abra; aos docentes do Departamento de Geologia da UFRN, especialmente Profs. Drs. E. F. Jardim de Sá, J. M. Sá, J. Salim e A. C. Galindo, durante a difícil fase de implantação do Curso de Geologia naquela Universidade; aos Profs. Drs. R. Dall'Agnol e J. M. Lafon da UFPA, colegas de pesquisas e discussões; a todos os colegas do IGc-USP, em particular ao Prof. Dr. R. Machado pelas suas sugestões quanto à melhoria de boa parte do texto original (escrito parcialmente em inguês e portuglês); a todos os alunos que conseguiram agüentar minhas aulas; e, finalmente porém sempre em primeiro lugar, à minha esposa Iris, pela paciência durante boa parte da minha carreira no Brasil. 


\section{CAPITULO 2: ASSOCIAÇÕES DE ROCHAS VULCÂNICAS E METAVULCÂNICAS}

\subsection{Suites recentes}

\subsubsection{Comentários gerais}

A elaboração da Tese de Doutorado intitulada "Petrogênese em Arcos de lihas" (McReath 1972) deu-se numa época em que a diversidade magmática neste ambiente tectônico ficava cada vez mais evidente. A importância dos toleiítos de arcos como manifestações magmáticas precoces a curtas distâncias das fossas oceânicas profundas já tinha sido levantada para os casos do arquipélago de Fiji (Jakes \& Gill, 1970), do arco de ilhas Sandwich do Sul (Baker, 1968), e do vulcanismo do Japão.(Kuno, 1966).

Da mesma forma, achava-se que as diferenças petrogenéticas entre as séries cálcio-alcalina e toleiítica pudessem originar-se essencialmente por diferenças nas condições de fugacidade de oxigênio (Osborn, 1959). A série cálcio-alcalina evoluiria sob codições de maior fugacidade conduzindo à estabilização da magnetita. Isso inibe o enriquecimento do ferro às custas do magnésio e promove o enriquecimento de sílica e da soma dos álcalis com uma razão praticamente constante de $\mathrm{Fe} / \mathrm{Mg}$, o que caracteriza a série cálcio-alcalina. Na evolução da série toleiítica, a baixa fugacidade de oxigênio inibe a formação da magnetita, e conduz ao enriquecimento de ferro às custas do magnésio, juntamente com o menor enriquecimento ou mesmo empobrecimento da sílica na fase inicial da diferenciação. Após a proposta de Osborn, ficou evidente que a participação ou não da magnetita durante o processo de cristalização fracionada representa uma parte, apenas, da petrogênese da série cálcioalcalina.

Estudos de estabilidade dos anfibólios sob condições magmáticas (Yoder \& Tilley, 1962; Green \& Ringwood, 1967) já demonstravam a possibilidade de membros da família da hornblenda cristalizarem-se a partir de diferentes tipos de magmas, desde máfico até félsico, sob pressões relativamente baixas. Levando-se em conta a solubilidade d'água nos diversos magmas (Burnham \& Jahns, 1962; Hamilton et al., 1964), bem como sua provável quantidade em sistemas magmáticos naturais, concluise que a saturação em água seria alcançada apenas a baixas pressões $(<10 \mathrm{~kb})$, tal 
como proposto por Lewis (1971). Análises de anfibólios presentes ern nódulos máficos associados a suítes cálcio-alcalinas (Lewis, 1964; Rea, 1970) demonstram que eles contém altos teores de $\mathrm{Al}^{\mathrm{i}}$, com suas composições sendo, portanto, nefelinanormativas. Eles são acompanhados, muitas vezes, por magnetita titanífera. Esta associação do anfibólio e magnetita representa um conjunto cujo fracionamento conduz a forte enriquecimento da sílica, mantendo-se a razão $\mathrm{Fe} / \mathrm{Mg}$ aproximadamente constante.

Embora a noção de que a cristalização fracionada de magma basáltico de origem mantélica seja um processo petrogenético muito importante em arcos de ilhas, a hipótese de que andesitos pudessem ser produzidos por fusão parcial de crosta oceânica subdutada começava a ganhar apoio, no contexto da recém-formulada teoria de tectônica de placas. O papel da reciclagem de crosta oceânica como modelo de geração da crosta continental em duas etapas, partindo do manto superior, foi proposto por Taylor et al. (1969).

No final dos anos 60 e do início dos anos 70 , surgiu a possibilidade de testar quantitativamente modelos de cristalização fracionada com base no cálculo de balanço de massas dos elementos maiores (Bryan et al. 1969). As primeiras tentativas de entender o comportamento dos elementos em traços durante processos de cristalização fracionada e de fusão parcial com base nas leis de partição dos elementos já tinham sido feitas (Gast, 1968) e simplificadas por Shaw (1970). A importância dos elementos incompativeis como indice em potencial do grau de solidificação foi reconhecida por Anderson \& Greenland (1969). Entretanto, foram poucos os testes quantitativos feitos com base nos elementos traços.

\subsubsection{Petrogênese em arcos de ilhas}

$\mathrm{Na}$ pesquisa executada, foram investigadas (i) rochas vulcânicas, nódulos plutônicos e minerais constituintes do arco vulcânico das Antilhas Menores, área clássica para o estudo da gênese da série cálcio-alcalina; (ii) rochas vulcânicas e seus fenocristais do arco vulcânico das ilhas Sandwich do Sul no Oceano Atlântico meridional, de composição toleítica predominantemente, máfica a intermediária; (iii) rochas vulcânicas e fenocristais das ilhas Tofua e Kao do grupo Tonga no Sudoeste do Oceano Pacifico, de composição toleiitica predominantemente e intermediária; e (iv) rochas vulcânicas e fenocristais, bem como nódulos plutônicos da ilha Decepção, a 
maior expressão sub-aérea do vulcanismo atual e recente no Estreito de Bransfield, Norte da Península Antártica.

2.1.2.1 A cristalização fracionada de magma basáltico hidratado Nessa parte da pesquisa, foram usadas amostras de rochas plutônicas cumulativas, que como nódulos acompanharam erupções piroclásticas recentes nas ithas de São Vicente, São Cristóvão e Monserrat nas Antilhas Pequenas. Foram analisados para elementos maiores e alguns traços, separados puros de plagioclásio cálcico, olivina moderadamente magnesiana, piroxênio cálcico aluminoso, hornblenda aluminosa e magnetita, bem como amostras de material intersticial de granulação muito fina, interpretado como líquido intersticial solidificado quando da erupção dos nódulos.

Os nódulos apresentam composição mineral correspondente a troctolito, olivina gabro e hornblenda gabro. Nesse aspecto, assemelham-se bastante a associações mineralógicas presentes em intrusões de arcos de ilhas (por exemplo, o batólito da itha da Virgem Gorda, Antilhas Maiores (Martin-Kaye, 1959; Helsley, 1960), e em margens continentais, como exemplificado pelo gabro de São Marcos, uma pequena parte do batólito do Sul da Califórnia (Miller, 1935; Larsen, 1948; Larsen \& Draisen, 1950).

Pel;o exposto acima, fica evidente a importância de cristalização fracionada de magma basáltico aluminoso sob baixas pressões totais e elevadas pressões parciais d'água, como parte importante no petrogênese de andesitos cálcio-alcalinos. Sob essas condições, além da magnetita, estabilisa-se hornblenda aluminosa de composição nefelina-normativa e plagioclásio extremamente cálcico. $O$ fracionamento dessa associação fortemente subsaturado em sílica e com altos teores de ferro, promove o enriquecimento de silica sem enriquecimento em ferro, bem como o enriquecimento dos álcalis a uma razão $\mathrm{Mg} / \mathrm{Fe}$ aproximadamente constante, cujas tendências químicas caracterizam a diferenciação da série cálcio-alcalina. O fracionamento precoce do conjunto mineral acima até atingir uma composição andesibasáltica, seguido pelo fracionamento de uma associação hidratada composta de labradorita-bitownita, hornblenda e magnetita titanifera (fenocristais comuns em muitos andesitos) resulta na formação de proporções importantes de andesitos com $\mathrm{SiO}_{2} \mathrm{em}$ torno de $59 \%$.

Enquanto é perfeitamente possivel a diferenciação de magma máfico de alto-AI para andesito através do fracionamento de plagioclásio e piroxênio cálcicos, piroxênio 
não cálcico e magnetita, a proporção de andesito resultante é relativamente muito menor.

2.1.2.2 A cristalizaçãop de magma basáltıco sob condições essencialmente anidras Nas ilhas Sandwich do Sul, o andesito cálcio-alcalino não é a rocha dominante, fato este já revelado por Baker (1968). Três grups foram definidos com base nas razões $\mathrm{FeO} / \mathrm{MgO}$ : (i) um grupo tipicamento cálcio-alcalino com $\mathrm{FeO} / \mathrm{MgO}$ constante, que inclui andesitos típicos com dois piroxênios; (ii) um segundo grupo com discreto aumento de $\mathrm{FeO} / \mathrm{MgO}$; e (iii) um grupo com crescente aumento de $\mathrm{FeO} / \mathrm{MgO}$ ao longo da diferenciação, terminando com dacitos parecidos com os diferenciados ricos em ferro da Islândia, os islanditos. É interessante notar que estes ferrodacitos vítreos das ilhas Sandwich do Sul apresentam coloração tão escura, que inicialmente foram mapeados como basaltos.

As diferentes tendências de enriquecimento em ferro podem ser correlacionadas aos conjuntos mineralógicos observados. A manutenção ou leve aumento da razão $\mathrm{FeO} / \mathrm{MgO}$ ocorre em suítes que apresentam plagioclásio extremamente cálcico e com dois piroxênios, sendo rico ou pobre em cálcio, respectivamente. A olivina ou a magnetita podem estar presentes. De um modo geral, os minerais ferromagnesianos são moderatemente ricos no membro ferroso (por exemplo, Fo $\left.\mathrm{F}_{\sim 70}, \mathrm{En}_{\sim 70}, \mathrm{Wo}_{\sim 45} \mathrm{En}_{\sim 39} \mathrm{FS}_{\sim 26}\right)$. Forte aumento da razão FeO/MgO ocorre em suítes cujos basaltos apresentam plagiocásio cálcico, e podem apresentar olivina magnesiana e/ou augita. Estas rochas não contém ortopiroxênio e nem magnetita.

Além da diferenciação com base na razão $\mathrm{FeO} / \mathrm{MgO}$, foi possivel distinguir dois grupos com base nos teores em $\mathrm{K}_{2} \mathrm{O}$ : um grupo com teores muitos baixos neste óxido, correspondendo ao grupo com leve enriquecimento na razão $\mathrm{FeO} / \mathrm{MgO}$, outro grupo com teores mais altos deste óxido engloba tanto as rochas tipicamente cáicio-alcalinas quanto os toleiítos extremos.

As composições isotópicas de $\mathrm{Sr}$ apresentam variação significativa, sempre enquandrando-se contudo na faixa das rochas mantélicas (Gledhill \& Bakert, 19XX).

Concluiu-se, portanto, que nada havia contra a hipótese de que a petrogênese destas rochas seria resultado do fracionamento de um magma máfico, derivado por fusão do amnto superior.

O acervo de rochas coletadas pelos pesquisadores Baker, Harris e Reay nas ithas de Tofua e Kao, do grupo Tonga, inclui uma seção estratigráfica bastante 
completa da parte subaérea daquela ilha, que abrange os produtos dos últimos estágios construtivos de um antigo estratovulcão, bem como os da fase de colapso da caldeira central, e os da atividade subseqüente. A coleção da itha de Kao, praticamente desabitada e de acesso muito mais difícil naquela época, serviu apenas para caraterizar a natureza do vulcanismo.

Ao mesmo tempo, um grupo de pesquisadores da Universidade Nacional da Austrália e do Instituto Oceanográfico de Woods Hole fizeram uma amostragem em escala de reconhecimento das demais ilhas vulcânicas do arco recente (Bryan et al., 1972; Ewart et al., 1973). Uma investigação independente da itha de Tofua foi reportada por Baeur (1970).

As rochas vulcânicas da ilha de Tofua são predominantemente porfiriticas e contêm fenocristais de plagioclásio muito cálcico, augita aluminosa e raramente, olivina ou pigeonita. Apresentam variação composicional bastante restrita, de modo geral variando desde andesito basáltico até andesito. Baeur (1970) descreve apenas um derrame de dacito entre os produtos da fase vulcânica que antecedeu ao colapso da caldeira. Nos andesitos basálticos os minerais óxidos de Fe-Ti occrem como uma nuvem escura de grãos submicroscópicos no vidro vulcânico da massa fundamental, enquanto nos andesitos e no dacito encontram-se cristais maiores destes minerais.

De um modo geral, teores dos LILE e HFSE, incluindo-se os elementos terras raras pesadas, são relativamente baixos comparados aos teores comuns em suites cálcio-alcalinas.

As composições isotópicas de $\mathrm{Sr}$ situam-se na faixa de $\left({ }^{87} \mathrm{Sr}{ }^{86} \mathrm{Sr}\right)=0,7022$ 0,7046, com média de 0,7034 para a ilha de Tofua, e 0,7022 a 0,7048 (média 0,7031), para a ilha de Kao.

Encontram-se pequenos xenólitos de dunito em uma das lavas expelida de um conduto da caldeira (Bauer, 1970). As rochas piroclásticas expelidas durante a fase de colapso da caldeira, contém xenólitos de diorítos com uma associação mineralógica anidra que inclui $\leq 2 \%$ de magnetita modal.

$\mathrm{Na}$ ilha de Kao, encontram-se rochas vulcânicas porfiríticas que contém fenocristais de ortopiroxênio, juntamente com plagioclásio bastante cálcico e augita. Novamente, são andesitos basálticos a andesitos. Embora sejam semelhantes, mineralogicamente, aos andesitos cálcio-alcalinos, quimicamente são toleíiticos. 
2.1.2.3 Petrogênese das ilhas Shetland do Sul A itha de Deception é um dos poucos vulcões atualmente ativos da Antártica, que juntamente com ilhas Penguin e Bridgeman e dois vulcões submarinhos, formam uma província vulcânica recente, a sul das ilhas maiores do grupo Shetland do Sul. Este grupo apresenta rochas vulcânicas e plutônicas de idade terciária, formadas numa zona de subducção ativa há cerca de $10 \mathrm{Ma}$ atrás. Com exceção da ilha Penguin, os demais vulcões recentes associam-se a uma fossa estreita, com profundidade em torno de $2 \mathrm{~km}$, instalada no graben do Estreito de Bransfield. O assoaiho desse estreito é formado dominantemente por crosta basáltica. O vulcanismo dessa região foi gerado numa fase de extensão incipiente sobre uma extinta zona de subducção. No caso da ilha Deception, a presença de xenólitos graníticos semelhantes aos granitos andinos, presentes na Peninsula Antártica adjacente, sugere um o ambiente de transição entre crosta do arco de ilhas e crosta oceânica.

A ilha de Deception, embora tenha sido alvo de diversas visitas por expedições científicas desde o início do século 20 , foi descrita de maneira detalhada somente em 1961 por Hawkes. Subsequentemente, o vulcão entrou numa nova fase de atividade vulcânica em 1967, tendo sido visitado por expedições que mapearam as modificações decorrentes das erupções de 1967, 1969 e 1970, além de complementarem o trabalho anterior de Hawkes. As contribuições do candidato foram apresentada na Tese de Doutoramento, e em capítulos do Relatório Científico $\mathrm{N}^{\circ}$. 78 , publicado pelo Serviço Antártico Britânico (Baker et al., 1975). Outros estudos nessa mesma época foram conduzidos por Gonçales-Ferran \& Katsui (1970), GonçalesFerran (1971), e Gonçales -Ferran et al. (1971a, 1971b), enquanto diversas amostras da coleção britânica foram reanalizadas por Weaver et al. (1979).

Concluiu-se (McReath, 1972, 1975) que a suite de rochas de basalto a dacito presente na ilha de Deception apresenta caraterísticas mineralógicas e químicas que são transicionais entre subalcalinas e alcalinas. Destacam-se os teores altos de sódio em todos os termos, e a razão $\mathrm{Na}_{2} \mathrm{O} / \mathrm{K}_{2} \mathrm{O}$ geralmente alta. A suíte resulta do fracionamento de magma máfico sob condições de baixa pressão, inicialmente de baixa pressão parcial de oxigênio e de subsaturação em água. Sob essas condições,a associação inicial de minerais fracionados não incluia nem magnetita nem anfibólio. Após a diferenciação de basalto com alto teor de alumínio para basalto com alto teor de ferro, a diferenciação prosseguiu através do fracionamento de uma associação 
mineralógica que inclui óxidos de $\mathrm{Fe}$-Ti. O fracionamento produziu um volume reduzido de andesito em relação aos termos mais máficos, conforme a freqüência de distribuição dos termos observada na ilha.

Uma reavaliação (McReath, em preparação) dos dados disponíveis com base na aplicação de diagramas de discriminação de processos ígneos (referências, ver seção 2.2.2) e de classificações químicas recentes [por exemplo, La Roche et al. (1980)] confirma que a suite da itha Deception possui características das séries cálcioalcalina, alcalina e toleítica, e que a petrogênese não deve ser simples. Há grupos de amostras consistentes, tanto nos diagramas de classificação quanto nos de identificação petrogenética, que devem resultar de processos de diferenciação diferentes, partindo de magmas parentais diferentes. $O$ caráter sódico do magmatismo talvez se deva à participação de crosta oceânica subductada. Na situação de evolução tectônica atual, a suite talvez represente o produto de uma fase extensional, que antecederia à aglutinação do antigo arco das ilhas Shetland do Sul à Península Antártica.

\subsection{Associações metavulcânicas proterozóicas}

\subsubsection{Comentários preliminares e problemas gerais}

Um problema central na discussão da geoquimica de rochas meta-ígneas é a questão da modificação ou não da composição original devido aos processos metamórficos, especialmente aqueles ocorridos em sistema aberto. Nas pesquisas realizadas a cerca destas associações, abordou-se um ou outro aspecto desse problema.

Foram, out estão sendo investigadas, em maior ou menor detalhe, oito associações de metavuicânicas, representativas de ambientes tectônicos diferentes, com níveis diferentes de detalhamento: (i) metavuicânicas félsicas ${ }^{(1)}$ da região do Rio Paramirim, BA, pós-orogênicas ou anorogênicas, associadas provavelmente à formação de um rift; (ii) Máficas, intermediárias e félsicas do cinturão dobrado de Orós, $\mathrm{CE}$; também, pós-orogênicas ou anorogênicas, associadas provavelmente à formação

(1) Omite-se o prefixo "meta" dessas descrições sumárias. 
de um rift, ou de uma bacia extensional ensiálica; (iii) Vulcânicas do greenstone belt do Rio Itapicuru, $\mathrm{BA}$; com termos máficos formados em bacia de retroarco, e intermediários a félsicos, em arco de ilhas; (iv) Ultramáficas e máficas da Suíte Metamórfica Vila Nova, PA, formada provavelmente em bacia de retroarco; (v) Vulcânicas da bacia Jaibaras, Noroeste do Ceará, formadas numa bacia extensional; (vi) Metavulcânicas dos Grupos Itaberaba e São Roque, SP, formadas provavelmente em ambiente oceânico extensional e de subducção, respectivamente; (vii) Metamáficas das vizinhanças do lineamento Ribeira, SP, também com indícios geoquímicos de gênese em ambientes distintos, de extensão oceânica e subducção; e (viii) rochs vulcânicas da bacia de Camaquã, modificadas hidrotermalmente.

2.2.2 Problema da mobilidade dos elementos químicos em suites meta-ígneas, testes para detetar mobilizações, e a recuperacão de informacões petrogenéticas.

Pesquisas sobre este tópico foram conduzidas ao longo de oito anos, com apoio de bolsas de pesquisa concedidas pelo CNPq. Parte do trabalho desenvolvido envolveu a elaboração de um banco de dados sobre rochas ígneas não alteradas, representativas de diversos ambientes tectônicos ${ }^{(1)}$. Para as vulcânicas ultramáficas, foi necessário compliar as análises de komatiitos e rochas semelhantes, na maioria dos casos, já rochas metavulcânicas. Prioritariamente, buscou-se análises de rochas acompanhadas por informações complementares básicas, tais como natureza textural da rocha (por exemplo, no caso das vulcânicas: se afanítica ou porfirítica; neste último, procurou-se saber a natureza e quantidade dos fenocristais; para as plutônicas, se a textura era cumulática ou não; e assim por diante). Além disso, buscou-we casos em que os modelos petrogenéticos sugeridos apoiavam-se em evidências petrográficas e geoquímicas, incluindo-se os elementos maiores e traços e os isótopos. Em alguns casos, foi possivel utilizar dados geoquímicos apresentados para testar, mais a fundo, as possibilidades petrogenéticas.

No caso dos elementos maiores, foram utilizados procedimentos simples, tais como verificação da coerência das composições e a consistência das tendências em diferentes diagramas de variação, tais como (i) diagramas binários de teores de óxidos,

(1) Para a lista das fontes usadas, ver Apêndices 2.1 a 2.2 
inclusive os de Harker, e (ii) diagramas de razões de proporções moleculares de Pearce (1968). Algumas das conclusões e recomendações desta parte da pesquisa foram comunicadas por McReath \& Faraco (1993) e por Juliani \& McReath (1993).

A seguir, para as associações máficas passou-se a utilizar diagramas de evolução de composições magmáticas baseados nos resultados da petrologia experimental para baixas pressões ( $1 \mathrm{~atm}$ a $20 \mathrm{~kb} / 2 \mathrm{Gpa}$ ), tais como os elaborados por Cox. et al. (1979) e Walker et al. (1979). Esses diagramas indicm, tanto a natureza dos minerais em equilíbrio com o magma representado pela composição da rocha, quanto o caminho do fracionamento necessário para se chegar aos cotéticos ou eutéticos. Tais informações sãopimportantes para orientar a interpretação dos dados referentes aos elementos em traços.

Para os elementos traços foram usados gráficos considerados discriminantes para processos de cristalização fracionada, fusão parcial por lotes, e mistura de magmas: (i) A/B vs. A em escala logarítmica, onde $A$ e $B$ são elementos traços, diferentemente incompativeis; o diagrama foi proposto para distinguir entre os processos de cristalização fracionada e de fusão parcial (Treuil \& Joron, 1975); (ii) A vs. B em escala logarítmica, onde A A é um elemento traçoscompatível, e B, incompativel; também proposto para distinguir entre cristalização fracionada e fusão parcial (Loubet, 1983 em Allègre \& Hart 1978; Martin 1987); e (iii) exclusivanmente para a avaliação de mistura de magmas, o gráfico de $\left(C_{1}-C_{2}\right)$ vs. $\left(H-C_{2}\right)$, onde $C_{1}$ e $C_{2}$ são as concentrações de um determinado elemento nos dois componentes extremos de uma mistura, e $\mathrm{H}$ é a concemtração do mesmo elemento num magma híbrido formado pela mistura da fração em peso $f_{1}$ de $C_{1}$ e $f_{2}$, de $C_{2}$, onde $f_{1}+f_{2}=1$ (e consequentemente, $f_{2}=1-f_{1}$ ). No caso de uma mistura perfeita, o resultado é uma reta com inclinação de $f_{1}$ (Fourcade \& Allègre, 1981; Platvoeit, 1982).

Além das suites não alteradas, foram coletados exemplos de suítes de rochas modificadas, incluindo-se por exemplo: (i) fácies metamórficas/hidrotermais, tipicamente provenientes de sistemas com taxas rocha/consideradas altas, reconhecidas em ofiolitos e em sondagens da crosta oceânica, incluindo-se as "pedras marrons", xistos verdes, e anfibolitos; (ii) fácies metamórficas/hidrotermais, tipicamente provenientes de sistemas com taxas rocha/fluído consideradas baixas, em ambientes oceânicos e continentais. Esse banco de dados complementa estudos pioneiros feitos por Condie et al. (1977) e Jolly (1980) 
2.2.2.1 Os diagramas de Pearce. Pearce (1968) introduziu os diagramas de razões de proporções moleculares numa tentativa de simplificar a interpretação qualitativa dos diagramas de variação. Na sua discussão teórica do processo de cristalização fracionada, Pearce demonstra que os elementos cujos pesos são conservados no líquido diferenciado (suas concentrações aumentam) podem servir de componentes de referência, ou denominadores comuns nas razões moleculares. Em terminologia mais corrente, os componentes conservados são os elementos incompativeis, rejeitados pelas estruturas iônicas dos minerais em vias de cristalização. No caso de magma máfico, os minerais comumente precipitados a baixas pressões são olivina magnesiana, piroxênio cálcico e plagioclásio cálcico. Nesse caso, os componentes conservados incluem $\mathrm{K}_{2} \mathrm{O}$. No diagrama de razões de proporções moleculares (RPM) com $x=\mathrm{SiO}_{2}(\mathrm{~mol}) / \mathrm{K}_{2} \mathrm{O}(\mathrm{mol})$ versus $y=\mathrm{MgO}(\mathrm{mol}) / \mathrm{K}_{2} \mathrm{O}(\mathrm{mol})$, a cristalização fracionada de olivina magnesiana, a partir de magmas máficos magnesianos é definida através de uma reta cuja inclinação é $\mathrm{MgO}(\mathrm{mol}) / \mathrm{SiO}_{2}(\mathrm{~mol}) \approx$ 2,0 .

Para magmas félsicos, no entanto, todos os componentes químicos são compativeis, em graus diversos, com os minerais comumente presentes nessas rochas Assim, os diagramas RPM perdem sua base essencial, embora sempre seja possivel definir alguma tendência.

2.2.2.2 Críticas e defesas do método de Pearce. Passando praticamente despercebido logo após sua publicação, o método de Pearce tem estimulado uma discussão acirrada, inciuindo-se críticas centradas essencialmente na validade estatística de correlações entre razões com o mesmo denominador comum (Butler, 1986; Roolinson \& Roberts, 1986; Vines, 1987; Pearce, 1987. A utilização de denominadores diferentes, teoricamente capazes de evitar a imposição de falsas correlações, enfrenta o problema da escolha do segundo denominador (além de possíveis problemas analíticos relacionados à precisão analítica alcançada - ver adiante).

O $\mathrm{TiO}_{2}$, cuja determinação precisa é mais fácil na sua faixa de concentração típica de rochas máficas (ca. $0,8-\geq 2,5 \%$ ), pode servir de componente incompativel para a cristalisação precoce de magmas máficos, antes da participação importante do clinopiroxênio com o qual apresenta alguma compatibilidade, e antes da precipitação 
dos óxidos de Fe-Ti. Entretanto, para a maioria de magmas intermediários e félsicos, não é adequado devido a sua compatibilidade com os minerais comuns nessas rochas.

$\mathrm{O} \mathrm{P}_{2} \mathrm{O}_{5}$ pode servir como elemento conservado caso sua concentração não alcance o limite de solubilidade da apatita. De um modo geral, pode ser um componente conservado satisfatório em muitos magmas máficos. Contudo, são comuns exemplos de casos de saturação em apatita em magmas intermediários a félsicos.

A utilização do $\mathrm{P}_{2} \mathrm{O}_{5}$ e de alguns elementos traços incompatíveis (por exemplo, - $\mathrm{Zr}$ ) pode ser restrita pela falta de precisão analítica, o que é comum às baixas concentrações destes elementos em muitos magmas ultramáficos e máficos.

Um ponto pouco discutido é o fato de que mesmo com a utilização de denominadores diferentes nas razões de proporções moleculares, é inevitável o problema de correlação matemática entre as concentrações dos elementos conservados em suítes magmáticas produzidas por cristalização fracionada.

Deste modelo, continua a discussão sobre a validade estatística das correlações e o possivel significado petrogenético das correlações observadas. Em defesa de seu método, Pearce (REF) sugeriu que correlações que passem pela origem devem ser consideradas como suspeitas. Entretanto, tais correlações podem surgir entre dois componentes que, tanto quanto os denominadores, são incompativeis em relação à associação mineralógica fracionada. Podem surgir, por exemplo, em gráficos de $x=\mathrm{Al}_{2} \mathrm{O}_{3}(\mathrm{~mol}) /($ componente incompativel) vs. $y=\mathrm{CaO}(\mathrm{mol}) /$ componente incompativel) para komatiitos, correlações lineares cuja inclinação não está relacionada ao fracionamento do plagioclásio cálcico e, isto sim, reflete a razão $\mathrm{CaO} / \mathrm{Al}_{2} \mathrm{O}_{3}$ do magma e, por extensão, da sua fonte original.

Os testes conduzidos durante essa pesquisa não foram conclusivos. Em muitos casos os diagramas com denominadores ora comuns, ora diferentes, produziram resultados petrologicamente idênticos. Em outros casos os resultados com denominadores comuns são discordantes dos com denominadores diferentes. $E$ possível que estas divergências resultem da compatibilidade, pelo menos parcial, de um dos denominadores.

Testes de redutio ad absurdam incluiram a aplicação do métodos de Pearce a modelos observados e calculados dos resultados da petrologia experimental. Nestes casos, o processo petrogenético operante foi a cristalização fracionada de fases 
minerais cujas composições e proporções eram conhecidas. Nestes testes, os resultados inferidos pelo método de Pearce coincidiram com os dados das experiências.

Outro aspecto ainda não abordado na literatura publicada é o significado das tendências lineares: são exclusividades do processo de cristalização fracionada, ou podem também ser produzidas pelos processos de mistura ou de fusão parcial de rochas? Conclui-se que, da mesma forma que nos diagramas Harker, as distribuições lineares resultam de diversos processos.

2.2.2.3 O método de Beswick \& Soucie (1978) para a avaliação da retenção de composições primárias

Um subproduto do método RPM, apresentado por Beswick \& Soucie (1978), são as tendências igneas padrão em diagramas RPM com escalas logaritmicas (RLPM). A utilização de escalas logarítmicas conduz a uma compressão do espalhamento de pontos observado em diagramas com escala linear. Tal compressão condux ao ocultamento de detalhes referentes às variações de história evolutiva de cada suite. Entretanto, a conformidade de muitas suítes às tendênciaspadrão sugere que tais diferenças petrogenéticas não devem incluir mudanças significativas de modelos petrogenéticos, de uma suite para outra.

McReath (1993) incrementou a base de dados usada por Beswick \& Soucie (1978), incluindo análises de komatítos e komatiitos basálticos, de boninitos, e de várias suítes vulcânicas, num total de cerca de 800 análises. A adição das rochas ultramáficas resultou na extensão das tendências propostas por Beswick \& Soucie (op. cit.), bem como pelo leve alargamento dos envelopes de $90 \%$ das análises.

As tendências-padrão em diagramas que utilizam $\mathrm{TiO}_{2}$, como componente incompativel, refletem o fato de que este componente fica incorporado aos piroxênios e anfibólios cálcicos, micas como biotita e flogopita, e, principalmente, nos óxidos de Fe-Ti (McReath \& Faraco, 1993).

\subsubsection{A utilização de diagramas geoquímicos na identificacãa de ambientes tectônicos} de suites vulcânicas.

A utilização da geoquímica para avaliar o ambiente geotectônico de suítes vulcânicas partiu de Pearce \& Cann (1971). A proposta atraiu bastante atenção dos pesquisadores devido a sua simplicidade, pois com base em diagramas simples, padronizados a partir de suites (geralmente, recentes e inalteradas) de ambiente 
tectônico conhecido, e que envolvem elementos químicos cuja determinação (precisa e exata) encontra-se no alcance de muitos pesquisadores, parecia possivel determinar os ambientes tectônicos de suites mais antigas de ambientes incertos.

Há sucessivas propostas para diagramas que aproveitam os elementos maiores para tal finalidade. Para os elementos maiores, por exemplo, há uma proposta utilizando-se análise multivariante de fatores para composições de rochas máficas selecionadas de acordo com critérios de seleção rigorosos (Pearce, 1976). Outra proposta usa combinações simples dos elementos maiores, também para rochas máficas a intermediárias selecionadas (Pearce et al., 1977). Há, também, várias sugestões para a utilização dos elementos em traços (e.g. Pearce \& Cann, 1973;).

Embora não explicitada, a base teórica exigiria, para cada ambiente, homogeneidade das composições das rochas-fontes dos magmas máficos, graus semelhantes de fusão parcial destas rochas-fontes, e cristalização fracionada consistente dos magmas primários gerados pela fusão. Entre cada ambiente, é necessário que haja alguma diferença importante no processo petrogenético global. Considerando-se apenas as fontes dos basaltos, o manto-fonte dos basaltos mesooceânicos deveria ter diferença significativa do manto fonte dos basaltos continentais, que por sua vez, deveria se diferenciar do manto-fonte dos basaltos de arcos.

A maior parte dos diagramas foi elaborada a partir de bancos de dados com volume relativamente restrito, focalizando ambientes especificos.

Tentativas adicionais aplicando os diagramas em outras suites de ambientes conhecidos tiveram resultados diferentes, com algumas identificações corretas e outras, não. Enquanto não apareciam sugestões para a melhoria dos diagramas, aumentaram os casos de interpretações equivocadas dos ambientes tectônicos, a exemplo daqueles que basearvam-se em diagramas diferentes.

O ponto culminante disso foi em 1987, quando foram documentados exemplos dos basaltos continentais, identificados como suites geradas em ambientes de cordilheira meso-oceânica e de arco de ilha (Duncan, 1987; Marsh, 1987). Além disso, o próprio Pearce (1987) admitiu que a geoquímica, isoladamente, não é ferramenta suficientemente específica para resolver este tipo de problema. Notou que é necessário levar em conta também, aspectos geológicos tais como a associação litlógica presente, e colocou a presença ou ausência de enriquecimento do ferro como uma caracteristica de grande importância. 
Há algumas cuidados que podem minimizar este problema: (i) uma seleção mais adequada das rochas analisadas, com separação de acordo com suas texturas (vitrea, afanítica, escassamente porfiritica, e porfirítica; neste último caso, separam-se as rochas de acordo com a natureza dos fenocristais); (ii) uma seleção das análises destas rochas, separando-as em classes menores de acordo com critérios como índice de Mg\# ou de teores de MgO. Procurar-se-ia enfatizar os magmas menos diferenciados, tal como os que poderiam ter-se mantido em equilibrio com olivina mantélica ( $M g \# \geq 66-70$ ); e (iii) no caso das suítes que apresentam apenas composições evoluídas, é necessário fazer uma estimativa, por meios gráficos ou por cálculos, de composições menos diferenciadas (tal como a composição inferida para $\mathrm{MgO}=8 \%$ ). Mantém-se em andamento, tratamentos dos dados acumulados para testar essas sugestões.

Outro procedimento utilizado na identificação de ambientes geotectônicos aproveita os diagramas de variação multi-elementos ("spidergrams") em que os elementos estão sequenciados de acordo com critérios tais como incompatibilidade relativa aos minerais comuns de basaltos sob baixas pressões. De fato, algumas caracteristicas observadas nestes diagramas são bastante específicos. 0 empobrecimento de $\mathrm{Nb}$ relativo a $\mathrm{Ce}$ é uma característica típica (embora não completamente exclusiva) de rochas geradas sobre zonas de subducção. A combinação de baixos teores de $\mathrm{Na}_{2} \mathrm{O}, \mathrm{TiO}_{2}$ e $\mathrm{Zr}$ também é característica de rochas formados a partir de magmas derivados de manto peridotítico, muito empobrecido por episódios anteriores de fusão parcial. Normalmente, estas rochas também apresentam empobrecimento dos elementos terras raras leves (ETRL: La, Ce, e Pr) relativo aos elementos terras raras pesados (ETRP) quando formadas em cordilheras mesooceânicas, e não apresentam este empobrecimento de ETRL, quando formadas sobre zonas de subducção.

\subsubsection{Casos estudados}

2.2.4.1 As rochas vulcânicas félsicas da bacia do Rio Paraminim, Centro-Oeste da Bahia. Deu-se início às pesquisas sobre essa região como orientador da Dissertação de Mestrado do Sr. E. J. T. Dultra da UFBA (Dultra, 1977), que teve continuidade na Dissertação de Mestrado do Sr. E. F. Jardim de Sá (Jardim de Sá, 1979), também da UFBA. Alguns aspectos geológicos foram revistos durante as 
pesquisas conduzidas para a CBPM de 1982 a 1983 sobre a geoquímica de rochas na região de Lagoa Real (BA). Nesta fase da investigação, percebeu-se que rochas máficas de idade paleoproterozóica tardia ou mesoproterozóica, que não foram encontradas na seqüência vulcânica, estão presentes no embasamento na forma de anbibolito de granulação bastante fina (rocha metavulcânica hipabissal?), bem como gabro e anfibolito mais grossos. As afinidades químicas variam desde toleíticas continentais a levemente alcalinas. Estas pesquisas serviram para orientar a investigação de rochas meta-vuicânicas no cinturão dobrado de Orós (CE; ver adiante, seção 2.2.4.2).

Os resultados principais da pesquisa sobre as metavulcânicas fésicas, comunicados por McReath et al. (1978) e Jardim de Sá et al. (1978) e apresentados em McReath et al. (1981), demonstram que as rochas menos metamorfisadas são dacitos a riolitos com carateristicas alcalinas a levemente peralcalinas. O magmatismo é, portanto, bimodal máfico-félsico, bastante típico de rifts continentais. Os metamorfismos regional e hidrotermal conduziram ao re-equilíbrio do sistema isotópico $\mathrm{Rb}-\mathrm{Sr}$, durante o evento brasiliano e, talvez, durante o evento Espinhaço, quando também foi parcialmente mobilizado o sistema isotópico U-Pb (Cordani et al., 1992).

Por outro lado, as rochas mais modificadas por metamorfismo incluem (meta)riolitos porfiríticos não ou pouco deformados, com fenocristais arredondados de quartzo azul, albitizados, portadores de cianita, que perderam praticamente todo seu conteúdo de $\mathrm{K}$ e $\mathrm{Ca}$. As rochas mais modificadas por atividade hidrotermal e deformação tectônica são moscovita(sericita)-hematita xistos.

2.2.4.2 O cinturão dobrado de Orós, Estado do Ceará. Desenvolveu-se o projeto inicial para empresas associadas à Caraíba Metais Ind. Com. Ltda., com o objetivo de avaliar o potencial da seqüência metavulcanossedimentar e das metaplutônicas associadas que poderiam hospedar mineralizações de cobre e zinco. A investigação abordou o segmento de orientação E-W, e a parte setentrional do segmento de orientação $\mathrm{N}-\mathrm{S}$ do cinturão. Como resultado, identificou-se um depósito vulcano-exalativo associado às vulcânicas félsicas, incluindo-se turmalinitos maciços da fácies proximal, turmalinitos bandados com intercalações de chert, tufos félsicos bandados com intercalações de chert, mineralizados ou não de fenoblasts de pirita, formações feríferas bandadas, e na parte distal, formações manganíferas. 
Posteriormente, fez-se uma interpretação dos dados geoquímicos referentes às rochas meta-igneas (McReath, 1993), concluindo-se pela diversidade dos termos magmáticos presentes, e interpretando o ambiente de gênese como um rifte ou outra forma de extensão em ambiente continental..

Foi feita uma integração de dados em colaboração com o Prof. Dr. J. M. Sá, que concentrou suas pesquisas, incluindo a parte de geocronologia e geologia isotópica, sobre o segmento N-S do cinturão. Neste integração (Sá et al., 1995) concluiu-se que a associação meta-ígnea/metassedimentar representa os produtos depositados durante a instalação de um rift ensiálico, logo após a orogenia transamazônica.

2.2.4.3 O "greenstone belt" do Rio Itapicuru, Estado da Bahia. O candidato participou da interpretação de dados geoquímicos referentes às rochas meta-ígneas associadas à Faixa Weber, a sul do greenstone belt, com o intuito de verificar as possiveis relações entre essas rochas, e as meta-igneas da seção clássica, ao longo do Rio Itapicurú. As pesquisas utilizaram dados já existentes, notadamente os obtidos para duas Dissertações de Mestrado da UFBA por geólogos da DOCEGEO Superintendência Leste, bem como alguns dados novos obtidos para a elaboração do texto deTeixeira et al. (1990). Na Faixa Weber, não há a separação dos basaltos em tipos de alto-Ti e baixo-Ti, encontrada mais a norte (Kishida \& Riccio, 1980) e atrbuída a derivação dos dois tipos através de fusão parcial em graus diferentes a partir de fontes mantélicas diferentes (Silva, 1987). Além disso, não foram encontrados na Faixa Weber as rochas de afinidade komatiitica, presentes na seção tipo em sills (Silva, 1987). Por outro lado, as rochas máficas metaplutônicas são importantes na Faixa Weber. Estas rochas metaplutônicas constituem uma associação toleiítica com diferenciação muito forte, chegando a termos extremos ferrogabróicos ou ferrodioríticos cuja riqueza em ferro é tanto que foram identificados como formações ferriferas. As rochas diferenciadas são as hospedeiras da mineralização aurifera mais expressiva na região.

As metaplutônicas apresentam estilos de modificação metamórfica diferentes, incluindo-se cloritização \pm carbonatação além das modificações fortes que caraterizam a zona hidrotermalizada (Teixeira et al., 1990). Um estudo dos padrões de mobilização dos elementos (McReath,Teixeira e Marimon, inédito) demonstrou a dificuldade de 
encontrar uma base, a partir da qual se estabelece o cálculo de ganhos e perdas. Esta dificuldade deve-se à variação das concentrações de elementos traços em rochas com indices Mg\# semelhantes. Esta variação pode ser atribuída à variação da quantidade de magma diferenciado, aprisionado pelos agregados cristalinos durante a solidificação das rochas plutônicas. Não é, necessáriamente, o resultado de mobilizações dos elementos em graus diferentes.

2.2.4.4 A Suite Metamórfica Vila Nova na Serra do Ipitinga, NW do Estado do Pará. O candidato participou das pesquisas como orientador da Geol ${ }^{a}$ M. T. L. Faraco, da CPRM - SUREG - Belém, tanto na Dissertação de Mestrado, quanto na Tese de Doutorado da mesma, ambasdesenvolvidas na UFPA. A CPRM apoiou o projeto, quase que irrestritamente e posteriormente, e a pesquisa recebeu apoio financeiro tanto da FAPESP, para a obtenção de dados isotópicos, e da CAPES (bolsa sanduiche para a candidata), para a realização de estudos de inclusões fluídas na França. Foram gerados, portanto, muitos dados e, consequentemente, este candidato passou a participar mais ativamente das etapas interpretativas.

Em área de acesso muito dificil, a CPRM vinha desenvolvendo trabalhos de semi-detalhe nos Estados do Pará e do Amapá, complementando e ampliando os dados já obtidos na região pelo Projeto RADAMBRASIL. Nessa época, no final dos anos 70 e no início dos anos 80 havia muito interesse no Brasil em encontrar greenstone belts arqueanos, visto que os mesmos representam importantes alvos para mineralizações. Ao encontrar rochas meta-ultramáficas, às vezes, com agregados fibro-radiais de actinolita-tremolita, havia grande tendência de atribuir a essas rochas, protólitos komatíticos e, por extensão, de inferir uma idade arqueana. Dessa forma, a Suíte Metamórfica Vila Nova foi identificada como um greenstone belt arqueano (Jorge João et al., 1078; Montalvão, 1985).

Seqüências metavulcanossedimentares em grau metamórfico baixo a médio formam parte importante da Cinturão Maroni-Itacaiúnas, que abrange desde Venezuela oriental atéo Pará-Amapá, passando pelas Guianas. Já no início dos anos 80 , a idade desses greenstone belts foi determinada por sistemas geocronológicos diferentes como sendo do Paleoproterozóico (Gibbs \& Olszewski, 1982; Gruaus et al., 1985). Gibbs (1987) sugeriu a possibilidade de haver correlação entre esses cinturões e a Suite Vila Nova. Assim, levantou um ponto que necessitava de verificação. 
Além disso, as pesquisas da CPRM tinham revelado uma mineralização sulfetada, responsável por uma anomalia de condutividade. O condutor modelado possui amplo comprimento na região da Serra do Ipitinga, na divisa entre Pará e Amapá, sitio de atividades de garimpeiros de ouro. Numa área relativamente pequena, havia sido feita uma densa amostragem de afloramentos e blocos, bem como de testemunhos de três furos de sondagens, cada um com $\sim 200-300 \sim \mathrm{m}$ de profundidade. Apenas algumas amostras tinham sido descritas $e$ analisadas. $A$, portanto, Foi elaborado um projeto de pesquisa pela geol ${ }^{a}$ Faraco, que serviu inicialmente para o desenvolvimento de sua Dissertação de Mestrado, e, subsequentemente, foi aprofundado para sua Tese de Doutorado, envolvendo aspectos da petrologia, petrogênese e mineralizações da área.

As pesquisas petrográficas e geoquímicas resultaram na identificação das seguintes associações importantes:

(i) na parte metavulcânica, foram identificadas rochas ultramáficas como komatiitos (piroxeníticos), e rochas ricas em quartzo e clorita, juntamente como ortoanfibólio e cordierita. Essas últimas associam-se, intimamente, às rochas mineralizadas em sulfetos. As rochas metamáficas incluem anfibolitos predominantes, cujo quimismo assemelha-se em muitos aspectos ao das rochastoleiíticas de bacias de retro-arco e arcos de ithas modernos.

(ii) na parte metassedimentar, formações ferriferas bandadas (BIF) dos tipos óxido (BIFO) e silicato (BIFS). As BIFO apresentam padrões dos elementos terras raras (ETR) típicos de depósitos associados a ambientes vulcano-exalativos de origem hidrotermal, enquanto as BIFS assemelham-se, geoquimicamente, às argilas ricas em ferro, associadas aos ofiolitos fanerozóicos.

Concluiu-se que os rochas foram afetadas por quatro eventos metamórficos:

(i) O metamorfismo de fundo oceânico $\left(M_{1}\right)$, ocorrido numa célula hidrotermal, foi o responsável pela transformação de vulcânicas máficas em associações de quartzo e clorita, além de resultar na formação de mineralizações sulfetadas em zonas de descarga, e na deposição de BIFs vulcano-exalativas. Esse metamorfismo foi essencialmente sindeposicional, e ocorreu em 2,26Ga, aproximadamente.

(ii) O metamorfismo regional $\left(\mathrm{M}_{2}\right)$ foi responsável pela formação de paragêneses mineralógicas típicas da fácies anfibolito com pressão de $\leq \approx 5-7,5 \mathrm{~kb}$ $(500-750 \mathrm{MPa})$ e temperatura máxima $\approx 550^{\circ} \mathrm{C}$. Ao que parece, a maior parte dos 
anfibolitos formados durante este metamorfismo, e não afetados pelos metamorfismos subsequentes, possuem quimismo que refletem a ação de cristalização fracionada de magma basático sob baixa pressão. Assim, retiveram suas composições originais.

(iii) A seguir, durante fase cisalhante, incluindo-se talvez um componente de empurrão que pode ter promovido a imbricação de fatias do embasamento de alto grau e supracrustais, ocorreu metamorfismo hidrotermal retrogradante $\left(\mathrm{M}_{3}\right)$.

(iv) Finalmente, ocorreu a intrusão de corpos graniticos anorogênicos a 1,9Ga, causando metamorfismo de contato $\left(\mathrm{M}_{4}\right)$ com formação de hornfels.

$\mathrm{O}$ estudo dos isótopos de $\mathrm{Sr}$ e $\mathrm{Nd}$ revelou influências importantes dos processos metamórficos sobre a distribuição dos sistemas $\mathrm{Rb} / \mathrm{Sr}$ e $\mathrm{Sm} / \mathrm{Nd}$. Mudanças neste sistema refletem-se, também, no desenvolvimento de padrões dos elementos terras raras normalizados pelo condrito de Evensen et al. (1978), que não refletem processos magmáticos. Por outro lado, foi possivel traçar uma "errócrona" Sm-Nd em rocha total com idade aparente de $\sim 2,26 \mathrm{Ga}$, confirmando assim a proposta de Gibbs (1987) quanto à idade deste greenstopne belt. O metamorfismo $M_{3}$ teve efeito muito importante sobre o sistema $\mathrm{Rb}-\mathrm{Sr}$. As composições isotópicas de oxigênio retêm as composições primárias ou as desenvolvidas durante $M_{1}$.

\subsubsection{A região noroeste do Ceará A pesquisa sobre a Bacia de} Jaibaras e rochas associadas foi desenvolvida ao longo de dois anos como a parte prática da disciplina do Curso de Graduação em Geologia da UFRN. Os resultados principais encontram-se em Jardim de Sá et al. (1979). O candidato responsabilizou-se pela supervisão das atividades petrográficas relacionadas ao componente igneo, incluindo-se as rochas metavulcânicas e os granitóides de Meruoca e Mocambo. Além disso, reavaliaou dados químicos já apresentados pela CPRM. Concluiu-se que, pelo estado de modificação hidrotermal da grande maioria das rochas vulcânicas, e por uma parte das rochas plutônicas, é difícil identificar as afinidades químicas das rochas por procedimentos que utilizam apenas os elementos móveis, tais como os álcalis e os álcalis terrosos.

2.2.4.6 Os Grupos São Roque e Serra do Itaberaba nos arredores da Grande São Paulo. O candidato colabora neste projeto em andamento, coordenado pelo Prof. Dr. C. Juliani, através da seleção e da interpretação dos dados geoquímicos 
referentes aos componentes meta-ígneos, procurando avaliar os ambientes tectônicos de gênese das rochas, e às possiveis relações petrogenéticas em cada ambiente.

\subsubsection{Anfibolitos e outras metamáficas nas proximidades do Lineamento} Ribeira. Neste projeto em andamento, coordenado pelo Prof. Dr. G. da C. Campanha, o candidato colabora através da interpretação dos dados geoquímicos no sentido de verificar os ambientes tectônicos de gênese das rochas, e possiveis interrelações petrogenéticas

2.2.4.8Rochas vulcânicas na Bacia do Camaquã $\mathrm{Em}$ fase incipiente de desenvolvimento, esta pesquisa deverá auxiliar os trabalhos do Prof. Dr. A. R. F. César e seu grupo. Em princípio, após a experiência com as rochas da Bacia de Jaibaras (CE; ver seção 2.2.4.5), pretende-se usar o quimismo dos elementos menos móveis (tais como $\mathrm{Ti}, \mathrm{Zr}, \mathrm{Nb}, \mathrm{Hf}$ etc.) na tentativa de identificar as afinidades químicas destas rochas, em muitos caso, fortemente afetados por processos hidrotermais.

\subsection{Conclusões}

É claro que a geoquímica é parte integral de pesquisas sobre a petrogênese de rochas vulcânicas "frescas". O sucesso de modelamento dos processos ígneas a partir da geoquímica dos elementos, por outro lado, depende da complexidade dos processos. Fica evidente que a evolução de muitas suítes foi controlada, aparentemente, por cristalização fracionada a baixas pressões. Algumas suítes podem ter evoluídas por cristalização fracionada polibárica, e outras, por mistura de magmas.

Evidentemente, há casos em que os modelos simples não são suficientes para explicar a evolução petrogenética. Entretanto, mesmo num processo relativamente simples, como a assimilação/cristalização fracionada (De Paolo, 1981), é necessáiro fazer estimativas de parâmetros cujos valores são desconhecidos, tais como as composições do magma original e da rocha assimilada, bem como e a razão das massas de magma e da rocha assimilada. Assim, o successo do modelamento depende da adequação das estimativas feitas. Mesmo que estão melhorando as condições para se fazer estimativas razoáveis da razão de massas, o modelamento geoquímico ainda possui seu aspecto lotérico. 
Quanto à investigação de suites mais antigas de rochas metavicânicas, informações importantes podem ser obtidas, desde que se faça uma rigorosa seleção das análses químicas usadas. Para isto, é essencial fazer um exame petrgráfico cuidadoso para identificar o grau de modificação e, se possivel, a história metamórfica de cada amostra. Com aproveitamento das análises das rochas menos modificadas (neste sentido, anfibolitos monometamórficos parecem como bons candidatos), é possivel obter informações petrológicos válidos.

\subsection{Referências bibliográficas}

ALLĖGRE, C. J. \& HART, S. R., 1979. Quantitative models of trace element behaviour in magmatic systems. In: Allègre, C. J. \& Hart, S.R. (Eds.) Trace elements in igneous petrology. Elsevier, Amsterdam. pp 1-25

ANDERSON, A. T.; GREENLAND, L. P., 1969. Phopsphorus fractionationdiagram as a quantitative ibndicator of crystallizaton differentiation of basaltic liquid. Geochim. Cosmochim Acta, 33; 493.

BAKER, P.E., 1968. Comparative volcanology and petrology of the Atlantic island arcs. Bull. Volc.,32: 189-206.

BAKER, P. E., 1978. The South Sandwich Islands, III: Petrology and geochemistry. Brit. Ant. Surv., Sci. Rept.93

BAKER, P. E.; McREATH, I.; HARVEY, M. R.; ROOBOL, M. J. \& DAVIES, T. G., 1975. The geology of the South Shetland Islands: V. Volcanic evolution of Deception Island. British Antarctic Survey Scientific Report, No. 78, 81 pp.

BAEUR, G. R., 1970. The geology of Tofua island, Tonga. Pac. Sci., 24: 333-350

BESWICK, A. E. \& SOUCIE,G., 1978. A correction procedure for metasomaism in an Archean greenstone belt. Precamb. Res., 6: 235-248

BRYAN, W. B.; FINGER, L. W. \& CHAYES, F., 1969. Estimating proportions in petrographic mixing equations by least-squares approximation. Science, 163: 926-927

BRYAN, W. B.; STICE, G. D. \& EWART, A., 1972. Geology, petrography and geochemistry of Tonga. Jour. Geophys. Res., 77: 1566-1585

BURNHAM, C. W. \& JAHNS, R. H., 1962. A method for determining thje solubility of water in silicate melts. Amer. Jour. Sci., 260: 721-745 
BUTLER, H. C., 1986. The role of spurious correlation in the development of a komatitic alteration model. Jour. Geophys. Res., 91: 295-280

CONDIE, K. C.; VILJOEN, M. J. \& KABLE, E. J. D., 1977. Effects ofalteration on element distributions in Archean tholeiites from the Barberton greenstone belt, South Africa. Contrin. Mineral. Petrol.,64: 75-89

CORDANI, U. G.; IYER, S. S.; TAYLOR, P. N.; KAWASHITA, K.; SATO, K. \& MCREATH, I., 1992. Pb-Pb, Rb-Sr and K-Ar systematics of the Lagoa Real Uranium Province, South-Central Bahia, Brazil, and the Esponhaço Cucle (c. 1.5-1.0Ga). Jour. Sth. Amer. Earth Sci., 5: 33-46

COX, K. G.; BELL, J. D. \& PANKHURST, R. J., 1979. The interpretation of igneous rocks. Allen \& Unwin, Londres. $450 \mathrm{p}$.

DUNCAN, A. R., 1987. The Karoo igneous province - a problem area for inferring tectonic setting from basalt geochemistry. Jour. Volc. Geotherm. Res., 32: 13-34

EVENSEN, N. M.; HAMILTON, P. J. \& O'NIONS, R. K., 1978. Rare earth element abundances in chondritic meteorites. Geochim. Cosmochim Acta., 42: 11991212

EWART, A.; BRYAN, W. B. \& GILL, J. B>, 1973. Mineralogy and geochemistry of the younger volcanic islands of Tonga, S. W. Pacific. Jour. Petrol., 14: 429-465

FOURCADE, S. \& ALLĖGRE, C. J., 1981. Trace element behaviour in granite genesis; A case study from the Querigut complex (Pyrénées, France). Contrib. Mineral. Petrol., 76: 177-195

GAST, P. W., 1968. Trace eklement fractonation and the origin of tholeiitic and alakline magma types. Geochim. Cosmochim. Acta.,32: 1957-1086

GIBBS, A., 1987. Proterozoic volcani rocks of the northern Guiana Shield, South America. In; PHARAOH, T.C.; BECKENSALE, R. D. \& RICKARD, D. (Eds.), Geochemistry and mineralization in proterozoic volcanic suites. Geol. Soc. Lond., Spec. Publ. 33: pp. 275-288

GIBBS, A. K. \& OLSZEWSKI, W. J., Jr., 1982. Zircon U-Pb ages of Guyana greenstone-gneiss terrane. Precamb. Res., 17: 199-214

GONÇÁLEZ-FERRÁN, O. \& KATSUI, Y., 1970. Estudio integral del volcanismo cenozoico superior de las Islas Shetland del Sur, Antártica. Ser. Cient. Inst. antárt. Chileno, 1: 123-174 (Contrmes Inst. antárt. Chileno, No. 22) 
GONÇÁLEZ-FERRÁN, O.; MUNIZAGA, F \& MORENO, H., 1971 Sintese de la evolución volcánica de isla Decepción y la erupción de 1970. Ser. Cient. Inst. antárt. Chileno, 2: 1-14 (Contrnes Inst. antárt. Chileno, No. 24)

GREEN, T. H. \& RINGWOOD, A. E., 1968. Theorigin of the calc-alkaline igneous rock suite. Contrib. Mineral. Petrol., 18: 105-162

GRUAU, M.; MARTIN, H.; LEVEQUE, B. \& CAPEDEVILA, R., 1985. Rb-Sr and Sm-Nd geochronology of lower proterozoic granite-greenstone terrains in French Guiana, South America. Precamb. Res., 30: 63-80

HAMILTON, C. W.; BURNHAM, C. W. \& OSBORN, E. F., 1964. The solubility of water and effects of oxygen fugacity and water content on crystallization in mafic magmas. Jour. Petrol., 5: 21-39

HAWKES, D. D., 1981. The geology of the South Shetland islands: II. The geology and petrology of Deception Island, Falkland Island Dependencies Survey Scientific Reports, No. 27, 43 pp.

HELSLEY, C. E., 1960. Geology of the British Virgin Islands. Tese inedita de Doutorado, Universidade de Princeton, E. U. A. 217 pp

JAKES, P. \& GILL, J., 1970. Rare earth elements and the island arc tholeitic series. Earth Planet. Sci. Letters, 9: 17-28

JARDIM DE SÁ et al., 1979. Observações sobre a etratigrafia e seqüências ígneas da bacia de Jaibaras, Noroeste do Ceará. In: IX Simp. Geol. Nordeste, Natal. Bol. No. 7 (Atas), p. 30-38

JOLLY, W. T., 1980. Development and degradation of Archean lavas, Abitibi area, Canada, in the light of major element goechemistry. Jour. Petrol., 21: $323-363$

JORGE, JOÃO, X. De S.; FRIZZO, S. J.; MARINHO, P. A. da C.; CARVALHO, J. M. da A.; SILVA NETO, C. S.; SOUZA, A. N. De \& GUIMARÃES, L. R., 1978. Prjeto Sudoeste do Amapá. Relatório Técnico, CNPM/CPRM, Belém. 554 pp.

JULIANI, C. \& MCREATH, I., 1993. Petroquímica de metabasitos: Metodologia para identificação de alterações magmáticas e pós-magmáticas. Geologia -Ciência e Técnica. (CEPEGE/IGc-USP) 10: 50-96

KISHIDA, A. \& RICCIO, L., 1980. Chemostratigrafy of lava sequences from the Rio Itapicuru greenstone belt, Bahia, Brazil. Precamb. Res., 11: 161-178

KUNO, H., 1966. Lateral variation of basalt magma types across continental margins and island arcs. Bull. Volc., 29: 195-222 
LARSEN, E. S. Jr., 1948. Botholith and associated rocks of Corona, Elsinore and San Luiz Rey quadrangles, south Califronia. Geol. Soc. Amer., Mem. 29, 182 pp.

LARSEN, E. S. \& DRAISIN, W. M., 1950. Conposition of mineraks in the rocks of the southern California batholith. 18Inter.Geol. Congr. Rept. Part II, Sec. A., pp. 5579

LEWIS, J. F., 1970. Chemical composition and physical properties of magnetite from the ejected blocks of the Soufriere volcano, St. Vincent. Amer. Min., 55: 793807

MARSH, J. S., 1987. Basalt geochemistry and tectonic discrimination within continental flood basalt provinces. Jour. Volc. Geotherm. Res., 32: 35-49

MARTIN, H., 1987. Petroghenesis of archaean TTG suite from eastern Finland: major and trace element geochemistry. Jour. Petrol., 28: 921-953

MARTIN-KAYE, P. H. A., 1959. Report on the geology of the Leeward and British Virgin Islands. Govt. Offices, St. Lucia, British West Indies, 117 pp.

McREATH, I., 1972. Petrogenesis in island arcs. Umpublished Doctors thesis, University of Leeds. $110 \mathrm{pp}$.

MCREATH, 1., 1993. The proterozoic Orós belt, Northeast Brazil: Geochemically diverse meta-igneous rocks, lithological associations and tectonic implications. Geochim. Brasil.,7: 1451-1467

MCREATH, I. \& FARACO, M. T. L., 1993. Geochemistry of low-grade metavolcanic rocks: A review and suggestions for screening procedures. In: $4^{\circ}$ Congr. Bras. Geoq. (Brasilia). Resumos: p 86-89

MCREATH. I.; JARDIM DE SÁ, E. F. \& FRYER, B. J., 1978. Vulcânicas comenditicas da faixa Santo Onofre, centro-oeste da Bahia. In: XXX Congr. Bras. Geol. (Recife). Bol. No. 1 (Resumo)

MCREATH, I.; JARDIM DE SÁ, E. F. \& FRYER, B. J., 1981. As vulcânicas ácidas proterozóicas da região da Bacia do Rio Paraminim - Bahia. In: INDA. H. A. V.; MARINHO, M. M. \& DUARTE, F. B. (Eds) Geol. Rec. Minerais Estado da Bahia, Textos Básicos Vol 4, p. 121-134

MONTALVÃO, R. M. G. de, 1985. Petrologia das rochas máfico-ultramáficas do Spergrupo Vla Nova (greenstone belt) e Grupo Parima (greenstone belt) e encraves na região do Parima. In: 2 Simp. Geol. Amaz^0n9a, Belém. Anais, pp 110-124 
OSBORN, E. F., 1959. Role of oxygen pressue in the crystallization and differentiation of basalt magma. Amer. Jour. Sci., 257: 609-647

PEARCE, J. A., 1976. Statistical analysis of major elements in basalts. Jour. Petrol., 17: $15-43$

PEARCE, J. A., 1987. An expert system for the tectonic characterization of ancient volcanic rocks. Jour. Volc. Geotherm. Res., 32: 51-66

PEARCE, J. A. \& CANN, J. R., 1971. Ophiolite origin investigated by discriminant analysis using $\mathrm{Ti}, \mathrm{Zr}$ and $\mathrm{Y}$. Earth Planet. Sci. Letters, 12: 339-349

PEARCE, J. A. \& CANN, J. R., 1973. Tectonic setting of basic volcanics determined using trace element analysis. Earth Planet. Sci. Letters, 19: 290-300

PEARCE, T. H., 1968. A contribution to the theory of variation diagrams. Contrib. Mineral. Petrol., 19: 142-157

PEARCE, T. H., 1987. The identificatiobn and assessment of spurious trends in pearce-type ratio variation diagrams: a discussion of some stratistical arguments. Contrb. Mineral. Petrol., 97: 529-534

PEARCE, T.H.; GORMAN, B. E. \& BIRKETT, T. C., 1977. The relationship between major element geochemistry and tectonic environment of basic and intermediate volcanic rocks. Earth Planet. Sci. Letters, 36: 121-132

PLATVOEIT, B., 1982. M; elanges magmatiques dans le complexe annular de Porto, Corse. Compt. Rend. Acad. Sci. Paris, 204: $907-910$

ROLLINSON, H. R. \& ROBERTS, C. R., 1986. Ratio correlations and major element mobility in altered basalts and komatiites. Contrib. Mieral. Petrol.,93: 89-97

SÁ, J. M.; MCREATH, I \& LETERRIER, J., 1995. Petrology, geochemistry and geodynamic setting of proterozoic igneous rock suites of the Orós fold belt (Borborema Province, Northeast Brazil). Jour. Sth. Amer. Earth Sci, 8: 299-314

SHAW, D. M., 1970. Trace element fractionation during anatexis. Geochim. Cosmochim. Acta, 34: 237-243

SILVA, M. G., 1987. Geochimie, petrologie und tektonische entwickulung eins proterozoichen gruensteinguertels: Rio Itapicuru, Bahia, Brasilein. Tese inédita de Doutorado, Universidade de Feiburg, Alemanha.

TAYLOR, S.R.; KAYE, M.; WHITE, A. J. R.; DUNCAN, A. R. \& EWART, A., 1969. Genetic significance of $\mathrm{Co}, \mathrm{Cr}, \mathrm{Ni}, \mathrm{Sc}$ and $\mathrm{V}$ contents of andesites. Geochim. Cosmochim. Acta., 33: 275-286 
TEIXEIRA, J. B. G.; MARIMON, M. P. C.; KISHIDA, A.; XAVIER, R. P. \& MCREATH, I., 1990. The Fazenda Brasileiro gold deposit, Rio Itapicuru greenstone belt, Bahia: Geology, hydrothermal alteration and fluid inclusion studies. Econ. Geol., 85: 990-1009

TREUILL, M. \& JORON, J. M., 1975. Utilisation des éléments hygromagmatophiles pour la simpligication de las modèlisation quantitative des precessus magmatiques. Exemples de l'Afar e de la dorsade médioatlantique. Soc. It. Mineral. Petrol., 21: 125-174

VINES, K. J., 1987. Comments on Ratio correlations and major element mobility in altered basalts and komatites, by H. R. Rollinson and C. R. Roberts. Contrib. Mineral. Petrol. 97: 525-526

WALKER, D.; SHIBATA, T. \& LONG, St. E. de, 1979. Abyssal tholeites from the Oceanopgrapher fracture zone. II: Phase equilibria and mixing. Contrib. Mineral. Petrol.,70: 111-124

WEAVER, S. D.; SAUNDERS, A. D.; PANKHURST, R. J. \& TARNEY, J., 1979. A geochemical study of magmatism associated with the intial stages of back-arc spreading. Contrib. Mieral. Petrol, 68: 151-169

YODER, H. S. \& TILLEY. C. E., 1962. Origin of basalt magmas: an experimental study of natural and synthetic rock systems. Jour. Petrol., 3: 342-532 
Apendice 2.1 Fontes das análises de rochas vulcânicas frescas usadas no banco de dados ${ }^{(1)}$, divididas de acordo com ambiente tectônico e localização geográfica.

\begin{tabular}{|c|c|c|}
\hline Ambiente tectônico & Localização & Referência $^{(2)}$ \\
\hline \multicolumn{3}{|c|}{ Cordilheiras meso-oceânicas } \\
\hline \multirow[t]{4}{*}{ Ilhas sub-aéreas } & Azores & White et al. (1979) \\
\hline & Galápagos & McBimey \& Williams (1969) \\
\hline & Islândia & Wood et al. (1979); \\
\hline & Jan Mayen & Trónnes et al (1999). \\
\hline \multirow[t]{4}{*}{ Cordilheiras submersas } & Meso-atlântica & $\begin{array}{l}\text { Engel et al. (1965); Langmuir et al. } \\
\text { (1977); Bryan et al. (1979); Rhodes et al. } \\
(1979) ;\end{array}$ \\
\hline & Pacifico oriental & $\begin{array}{l}\text { Batiza \& Vanko (1984); Allan et al. (1989); Niu } \\
\text { et al. }(1996,1999)\end{array}$ \\
\hline & $\begin{array}{l}\text { So do Oceâno } \\
\text { Índico }\end{array}$ & Le Roex et al. (1983): Mahoney et al. (1992) \\
\hline & América-Antártica & Le Roex et al. (1985) \\
\hline Platôs submersos fósseis & EUA/Canadá & Lassiter et al. (1995) \\
\hline \multicolumn{3}{|c|}{ Crosta oceânica - ofiolitos } \\
\hline & Omã & Lippard et al. (1986) \\
\hline & Finlândia & Peltonen et al. $(1996 ; 1998)$ \\
\hline \multicolumn{3}{|l|}{ Arcos de ilhas } \\
\hline \multirow[t]{2}{*}{ Imaduros } & $\begin{array}{l}\text { Ilhas Tonga- } \\
\text { Kermadec }\end{array}$ & $\begin{array}{l}\text { Brothers (1967); Baeur (1970); Brothers \& } \\
\text { Martin (1970); Brothers \& Searle (1970); } \\
\text { Bryan (1971); McReath (1972); Bryan et al. } \\
\text { (1972); Ewart et al. (1973); Ewart et al. (1998) }\end{array}$ \\
\hline & $\begin{array}{l}\text { Ilhas Sandwich do } \\
\text { Sul }\end{array}$ & $\begin{array}{l}\text { McReath (1972); Baker (1978); Pearce et al. } \\
(199 X)\end{array}$ \\
\hline \multirow[t]{2}{*}{ Maduros } & Antilhas Menores & $\begin{array}{l}\text { Baker (1963,1968); Lewis (1964, 1971); Rea } \\
\text { (1970, 197X); Tomblin (1964); }\end{array}$ \\
\hline & Mar Egeu & Nicholls $(1971 a, b)$ \\
\hline \multicolumn{3}{|l|}{ Margens continentais } \\
\hline & Cascatas, E. U. A. & Hughes \& Taylor (1986) \\
\hline
\end{tabular}




\begin{tabular}{|c|c|c|}
\hline \multicolumn{3}{|l|}{ Apêndice 2.1 (cont) } \\
\hline Ambiente tectônico & Localização & Referência ${ }^{(2)}$ \\
\hline \multicolumn{3}{|l|}{ Bacias de retro-arco } \\
\hline & Tonga-Kermadec & Jenner et al. (1987); Gamble et al. (1996) \\
\hline & S. Sandwich & $\begin{array}{l}\text { Hawkesworth et al. (1977); Saunders \& } \\
\text { Tarney (1979); Gledhill \& Baker (1973) }\end{array}$ \\
\hline Sobre subducção fóssil & Sth. Shetland Is. & $\begin{array}{l}\text { McReath (1972); Weaver st al.(1979); Keller } \\
\text { \& Fisk (1992) }\end{array}$ \\
\hline \multicolumn{3}{|l|}{ Ambientes intra-placas } \\
\hline Ilhas oceânicas & Avaí & $\begin{array}{l}\text { MacDonald \& Katsura (1964); Wilkinson } \\
\text { (1991); Fodor \& Galar (1997) }\end{array}$ \\
\hline \multirow[t]{7}{*}{ Basaltos continentais } & Bacia do Paraná & $\begin{array}{l}\text { Mantovani et al. (1985); Belieni et al. } \\
\text { (1986); Petrini et al. (1987); Piccirillo \& Melfi } \\
\text { (1988); Picirillo et al. }(1988,1989) ;\end{array}$ \\
\hline & Deccã, Índia & $\begin{array}{l}\text { Paul et al. (1977); Cox \& Hawkesworth (1985); } \\
\text { Mahoney (1988); Lightfoot et al. (1990); Peng } \\
\text { et al. (1998) }\end{array}$ \\
\hline & Etiópia & Mohr \& Zanettin (1988) \\
\hline & Karoo & $\begin{array}{l}\text { Walker \& Poldevaart (1949); Vail et al.(1969); } \\
\text { Cox (1988) }\end{array}$ \\
\hline & $\begin{array}{l}\text { Planalto do Rio } \\
\text { Colômbia, EUA }\end{array}$ & Hooper (1988); Cartson \& Hart (1988) \\
\hline & $\begin{array}{l}\text { Província atlântica } \\
\text { terciária }\end{array}$ & $\begin{array}{l}\text { Moorbath \& Thompson (1980); Fram \& Lesher } \\
\text { (1997) }\end{array}$ \\
\hline & Outras áreas & $\begin{array}{l}\text { McDougall (1962); Hawkes (1966); Hotz } \\
\text { (1963) }\end{array}$ \\
\hline
\end{tabular}


Apêndice 2.2

Análises de komatítos, komatiitos

basáticos, picritos

e ferropicritos, e boninitos

(a) komatítos e komatítos basáiticos

\begin{tabular}{|c|c|c|}
\hline Idade & Localização & Referência \\
\hline \multicolumn{3}{|l|}{ Fanerozóico } \\
\hline & Ilha Gorgona, Colômbia & $\begin{array}{l}\text { Echeverria (1980); Echeverria \& Aitken } \\
\text { (1986); Kerr et al. (1996) }\end{array}$ \\
\hline & Provincia do Caribe & $\begin{array}{l}\text { Mottana et al. 1985); Spadea et al. (1989); } \\
\text { Kerr et al. (1996) }\end{array}$ \\
\hline \multicolumn{3}{|l|}{ Precambriano } \\
\hline & África do Sul & $\begin{array}{l}\text { Viljoen \& Viljoen (1969a,b); Hermann et al. } \\
\text { (1976); Hawkesworth \& O'Nions (1977); de } \\
\text { Wit et al. (1987) }\end{array}$ \\
\hline & Austrália & Arndt \& Lesher (1985); Gruau et al. (1987) \\
\hline & Brasil & $\begin{array}{l}\text { Teixeira \& Danni (1979a, b); Saboia } \\
\text { \&Teixeira (1980); Pires (1983); Jahn \& } \\
\text { Schrank (1983); Padilha et al. (1985); } \\
\text { Teixeira et al.(1987); Arndt et al. (1989); } \\
\text { Rivalenti et al. (1989) }\end{array}$ \\
\hline & Canadá & Arndt et al. (1977); Arndt \& Nesbitt (1984) \\
\hline & Finlândia e Norüega & $\begin{array}{l}\text { Jahn et al. (1980); Barnes \& Often (1990); } \\
\text { Korkiakoski (1992) }\end{array}$ \\
\hline & Índia & $\begin{array}{l}\text { Das \& Achanja (1985); Rajaman et al. } \\
\text { (1985) }\end{array}$ \\
\hline & Rodésia (Zimbabwe) & $\begin{array}{l}\text { Bickle et al. (1975); Barnes et al. (1983); } \\
\text { Nisbet et al. (1987); Cattell \& Arndt (1987( }\end{array}$ \\
\hline & Global & $\begin{array}{l}\text { Brooks \& Hart (1974); Nesbitt \& Sun (1976); } \\
\text { Sun \& Nesbitt (1981) }\end{array}$ \\
\hline
\end{tabular}


(b) Picritos e ferropicritos

\begin{tabular}{|l|l|l|}
\hline \multicolumn{1}{|c|}{ Idade } & \multicolumn{1}{|c|}{ Localização } & \multicolumn{1}{c|}{ Referência } \\
\hline Fanerozóico & Canadá & $\begin{array}{l}\text { O'Nions \& Clarke (1972); Gale (1973); Francis } \\
(1985)\end{array}$ \\
\hline Proterozóico & Canadá & $\begin{array}{l}\text { Paktune (1984); Stone et al. (1987); Stone et al. } \\
(1995)\end{array}$ \\
\hline & Estados Unidos & Green \& Schulz (1977) \\
\hline & Rússia & Hanski \& Smolkin (1989) \\
\hline
\end{tabular}

(c) Boninitos

\begin{tabular}{|l|l|l|}
\hline \multicolumn{1}{|c|}{ Idade } & \multicolumn{1}{|c|}{ Localização } & \multicolumn{1}{c|}{ Referência } \\
\hline Cambriano & Região do Pacífico & Crawford et al. (1989 \\
\hline Proterozóico & Antártica & Kuehner (1989) \\
\hline
\end{tabular}

(1) Aproximadamente $75 \%$ dos dados está armazenado em arquivos NEWPET (Clarke, 1992).

(2) As referências para os apéndices que não constam das citadas no texto são fornecidas aqui de forma abreviada.

(A) Allan, J. F.et al., Jour. Petrol, 30: 1245-1298 (1989); Arndt, N. T., Geol. Assoc. Canada, Spec. Paper 14, pp 617-657; Arndt, N. T. \& Lesher, C. M., Geochim. Cosmochim. Acta, 56: 4191-4294 (1979); Arndt, N. T. \& Nesbitt, R. W. In: Kröner, A. et al. (Eds.) Archaean Geochemistry. Springer-Verlag, Berlin. pp. 99-114 (1984); Arndt, N. T. et al., Jour. Petrol., 18: 319-369 (1977); Arndt, N. T. Et al., Contrib. Mineral. Petrol., 101: 187-197 (1989);

(B) Barnes, S.-J. \& Often, M., Contrib. Mineral. Petrol., 105: 42=54 (1990); Barnes, S.-J. et al., Contrib. Mineral. Petrol., 3: 293-308; Batiza, R. \& Vanko, D. A., Jour. Geophys. Res., 89: 11,23511,260; Belieni, G. et al., Jour. Petrol., 27: 915-944 (1986);Bickle, M. et al., Earth Planet. Sci. Lett., 27: 155-162 (1975); Brooks, C. \& Hart, S. R., Geology,: 2: 107-110 (1974); Brothers, R.N., Bull. Volc., 31: 17-19 (1967); Brothers, R. N. \& Martin, K. R., Bull. Volc., 34: 330-346 (1970): Brothers, R. N. \& Searle, E. J., Bull. Volc. 34: 7-37 (1970); Bryan, W. B., Geol. Soc. Amer. Bull. 82: 2799-2812 (1971); Bryan, W. B. et al., Tectonophys., 55: 63-85 (1979);

(C) Carlson, R. W. \& Hart, W. K. In: MacDougall, J.D. (Ed) Continental Flood Basalts. pp. 35-61; Cattell, A. \& Arndt, N. T., Contrib. Mineral. Petrol., 97: 218-227 (1987); Cox, K. G. In: 
MacDougall, J.D. (Ed) Continental Flood Basalts. pp. 239-271 (1988); Cox, K. G. \& Hawkesworth, C.J., Jour. Petrol., 26: 355-377 (1985); Crawford, A. J. et al., In: Crawford, A. J. (Ed.), Boninites. Unwin Hyman, London. pp. 1-49

(D) Das, M. \& Acharya, D., 28 Inter. Geol. Congr., Washington, Absts. V. 1, p. 368 (1986); de Wit, M. T. et al., Jour. Afr. Earth Sci., 6:L 681-730 (1987);

(E) Echeverria, L. M., Contrib. Mineral. Petrol., 73: 253-265 (1980); Echeverria, L. M. \& Aitken, B. G., Contrib. Mineral. Petrol., 92: 428-436 (1986); Engel , A. E. et al., Geol. Soc. Amer. Bull. 76: 719-734 (1965); Ewart, A. et al., Jour. Petrol., 33: 331-368 (1998);

(F) Fodor, R. V. \& Galar, P., jour. Petrol., 38: 561-624 (1997); From, M. S. \& Lesher, C. E., Jour. Petrol. 38: 231-275 (1997); Francis, D., Contrib. Mineral. Petrol., 89: 144-154 (1985);

(G) Gale, N., Earth Planet. Sci. Lett., 18: 22-28 (1973); Gledhill, A. \& Baker, P. E., Earth Planet. Sco. Lett., 19: 369 (1973); Green, J. C. \& Schulz, K. J., Can. Jour. Earth Sci., 14: 2181-2192 (1977); Gruau, G. Et al., Earth Planet. Sci. Lett., 85: 105-116 (1987);

(H)Hanski, E. J. \& Stolkin, V. F., Precamd. Res., 45: 563-83 (1989); Hawkes, D. D., Geol. Soc. Amer., Bull, 77: 1131-1158 (1966); Hawkesworth, C. J. \& O'Nions, R. K., Jour. Petrol., !8: 487520 (1977); Hawkerworth, C. J. et al., Earth Planet. Sci. Lett., 36: 253-262 (1977); Hermann, A. G. Et al., Contrib. Mineral. Petrol., 59; 1-12 (1976); Hooper, P.R., In: MacDougall, J.D. (Ed) Continental Flood Basalts. pp. 1-33; (1988); Hotz, P. E., Geol. Soc. Amer., Bull., 64: 675-704 (1963); Hughes, S. S> \& Taylor, E. M., Geol. Soc. Amer., Bull. 97: 1024-1036 (1986);

(J) Jahn, B.-M. \& Schrank, A., Precamb. Res., 21: 1-20 (1983); Jahn, B.-M. et al., Jour. Petrol., 29: $201-244$ (1980);

(K)Keller, R. A. \& Fisk, M. R. p. 155-169 In Parsons, L. M. et al. (Eds), Geol. Soc. Spec. Publ. No. 60 (1992); Kerr, A. C. et al., Lithos 37: 245-260 (1996); Kerr, A. C. et al, Contrib. Mineral. Petrol. 124: $29-43$ (1996); Korkiakoski, E. A., Geol. Sun. Finland, Bull 360 (1992); Kuehner, S. M., In: Crawford, A. J. (Ed.), Boninites. Unwin Hyman, London. pp. 208-224

(L) Langmuir, C. H. Et al., Contrib. Mineral. Petrol., 70: 319-339 (1977); Lassiter, I. C. et al., Jour. Petrol., 36: 983-1009 (1995); Le Roex et al. (1983); Le Roex et al. (1985); Lippard, S. J. et al., Geolo. Soc. London, Mem. No. 11;

(M) MacDonald \& Katsura (1864); Mahoney, J. et al., Jour. Geophys. Res., 97: 19.771-19.790 (1992); McDougall, I., Geol. Soc. Amer., Bull., 73: 299-316 (1962; Mantovani, M, S. M. et al., Jour. Petrol., 26: 187-209 (1985); McBirney \& Williams, 1969; Moorbath, S. \& Thompson, R. N., Jour. Petrol., 21: 295-321 (1980); Mottana, A. et al., Chem. Geol., 50: 351-368 (1985);

(N) Nesbitt, R. W. \& Sun, S. S., Earth Planet. Sci. Lett., 31: $433-543$ (1976); Nicholls, I. A., Tectonophys., 11: $377-385$ (1971); Nicholls, I. A., jout. Petrol., 12: 67-119 (1971); Nisbet, E. G. 
Et al., Geology, 15: 1147-1150 (1987); Niu, Y, et al., Jour. Geophys. Res., 101: 27,711-27.733 (1996); Niu., Y. et al., Jour. Geophys. Res. 104: $7067-7087$ (1999);

(O) O'Nions, R> K. \& Clarke, D. B., Earth Planet. Sci. Lett., 15: 436-446 (1972);

(P) Padilha et al., Rev. Bras. Geoc.,15: 74-84 (1985); Paktune, A. D., Contrib. Mineral. Petrol.,88: 348-357 (1984); Pearce, J. A. et al., Jour. Petrol.,39: . (1998); Peltonen, K. et al., Jour. Petrol., 37: 1359-1383 (1996); Peltonen, K. Et al., Jour. Petrol.,39: 297-329 (1990); Peng, J. X. Et al., Jour. Geophys. Res,., 103: 29.843-29.865 (1998); Petrini, R. et al., Jour. Petrol., 28 : 701-726 (1987); Piccirillo, E. M. \& Melfi, A. J. (Eds.) The mesozoic flood volcanism of the Paraná basin. IAG/USP, São Paulo. 600 pp. (1988); Piccirilo, E. M. et al. In: MacDougall, J.D. (Ed) Continental Flood Basalts. pp. 199-238 (1988); Piccirillo, E. M. et al., Chem. Geol.,75: 103-122 (1989); Pires,. Rev. Bras. Geoc., 13: 106-112 (1983);

(R) Rajamam, V. Et al., Jour. Petrol.,26: $92-123$ (1985); Rhodes, J. M. et al., Tectonophys., 55: 35-61 (1979); Rivalenti, G. Et al., Jour. Petrol., 30: 175-197 (1989);

(S) Saboia, L. A. de \& Teixeira, N. A., Rev. Bras. Geoc.,10: 28-42 (1980); Spadea, P. Et al., Chem. Geol. 54: 303-321 (1989); Stone, W. E. et al., Can. Jour. Earth. Sci., 24: 2537-2550 (1987); Stone, W. E. et al., Chem. Geol., 121; $51-71$ (1995);

(T) Teixeira, N., \& Danni, J., Rev. Bras. Geoc., (: 151-158 (1979); Teixeira, N. A. et al., Rev/ Bras. Geoc.,17: 209-220 (1987); Tomblin (1964); Viljoen, M. J. \& Viljoen, R. P., geol. Soc. Sth. Africa, Spec. Publ. 2, pp. 221-244 (1969);

(W) Walker, F. \& Poldevaart, A., Geol. Soc. Amer., Bull,60: 591-706 (1949);White, W. M. et al., Contrib. Mineral. Petrol., 69: 201-213 (1979); Wilkinson, J. F. G., Jour. Petrol., 32: 863-908 (1991); Wood et al. (1979) 


\section{CAPÍTULO 3: ASSOCIAÇÕES DE ROCHAS PLUTÔNICAS E METAPLUTÔNICAS}

\subsection{Associações máficas-ultramáficas, máficas e diferenciadas}

\subsubsection{Intrusão acamadada de Skaergaard, Gröenlândia Oriental.}

A primeira investigação da geoquímica de rochas plutônicas feitas pelo candidatofoi com relação ao comportamento do estrôncio em rochas da intrusão acamadada de Skaergaard, Groenlândia oriental (McReath, 1963). A discussão foi condicionado fortemente pelo modelo de cristalização fracionada de magma basáltico, elaborado por Wager e colaboradores (ver, por exemplo, Wager \& Brown 1967). 0 estudo demonstrou o forte controle sobre o comportamento do estrôncio pela sua incorporação preferencial no plagioclásio.

\subsubsection{Intrusão máfica ultramáfica associada às mineralizacões cupriferas de Caraiba.} BA.

Mais adiante, retomou-se as pesquisas a respeito de suites toleíticas numa pesquisa sobre as rochas hospedeiras das mineralizações de cobre no vale do Rio Curaçá, especialmente, aquelas da área da mina de Caraiba. Uma das teorias correntes na época entre alguns dos geólogos da mina, pertencente à empresa mineradora Caraíba Metais Ind. Com. Ltda., era de que a gênese dessas rochasestava relacionada a um sill composto por três ciclos de injecção e diferenciação de um magma máfico.

A pesquisa (McReath, 1985) foi realizada principalmente em testemunhos de sondagens da parte oriental do depósito, onde se localizam as minas subterrânea e a ceu aberto. Os resultados confirmaram a hipótese acima, bem como demonstraram que os três ciclos possuiam diferenças com relação à alimentação magmática do sill a partir de uma câmara maior que se diferenciava. A mineralização primária ocorre como uma massa semi-contínua que engloba olivina e piroxênios nos piroxenitos inferiores, o que sugere uma separação relativamente precoce de um líquido sulfetado imiscivel a partir do magma parental homogêneo. As mineralizações nas partes intermediária e superior são disseminadas, sugerindo que nesse caso uma separaçãotardia do líquido 
sulfetado teria ocorrido, após formação de um retículo de cristais silicáticos que retiveram o líquido sulfetado nos interstícios.

Os estudos das amostras da parte oeste do depósito revelaram que, na região de contato entre o sill $e$ as rochas encaixantes, as rochas ultramáficas foram tramsformadas de ortopiroxenitos para clinopiroxenitos, contendo como variedade mineralógica o dialágio, cuja forte partição basal confunde-se com uma clivagem. São cristais cristais euédricos englobados parcialmente por anidrita na textura subofítica. Alguns pesquisadores levantaram a possibilidade de que as rochas encaixantes da mineralização continham horizontes evaporíticos. Existe a possibilidade, portanto, que o enxofre da mineralização tenha sido extraido, pelo menos parcialmente, das encaixantes.

\subsubsection{O Complexo Granultitico de Santa Catarina.}

Num estudo inciado em colaboração com o falecido Prof. Dr. M. C. H. Figueiredo, tentou-se uma análise dos dados existentes sobre este complexo granulítico. Um fato interessante a ser assinalado é a tendência comum dessas rochas de uma evolução cálcio-alcalina, a partir de magmas de composições máficas. Isto levou à conclusão de que pelo menos uma parte do complexo seja produto de processos petrogenéticos semelhantes aos que operam em arcos de ilhas modernos, ou seja, de uma crosta oceânica fria que, ao sofrer subducção passa inicialmente por desidratação. Os fluídos então liberados invadem a cunha mantélica sobrejacente, provocando alí a fusão parcial sob condiçōes parciaimente hidratadas. Isto produz um basalto aluminoso que passa por uma cristalização fracionada sob baixas pressões, forma tanto os termos piroxeníticos e ferrogabróicos por acumulação de cristais, quanto os termos intermediários e ácidos com padrões multi-elementos semelhantes aos das súites cálcio-alcalinas modernas (Figueiredo et al. 1997).

Por outro lado, uma parte do complexo não se enquadra neste esquema. Algumas rochas intermediárias apresentam padrões multi-elementos parecidos com os dos TTG arqueanos, em contraste com os padrões tipicamente cálcio-alcalinos (Basei et al., 1998). Assim, parte da associação pode ter sido gerada pela fusão direta da crosta oceânica em subducção. O magma então gerado mantém equilíbrio com um resíduo refratário eclogítico. Tal processo é típico do Arqueano, porém tem sido 
também registrado em determinados arcos de ithas modernos, o que poderia ser explicado pela subducção de crosta oceânica recém-criada e, portanto, ainda quente.

\subsubsection{As rochas meta-igneas da região de Brejo Seco, São João do Piaui, Estado do} Piauí.

A pesquisa fez parte da Dissertação de Mestrado na UFBA da Geol ${ }^{a}$ M. P. Marimon, Petrógrafa da DOCEGEO - Superintendência Leste (Marimon, 1990). projeto recebeu $\mathrm{O}$ apoio da DOCEGEO, e de um convênio mantido com entidades finlandesas para a obtenção de análises químicas. Foi também apoiado pelo $\mathrm{CNPq}$, na forma de Auxílio de Pesquisa para a obtenção de análises químicas complementares.

A associação de rochas meta-ígneas inclui metaplutônicas ultramáficas a máficas (metadunito/serpentinito mineralizado com cromita, metaperidotito serpentinizado; piroxenito e gabro) e básicas (leucogabro-anortosito mineralizado com minerais óxidos de Fe-Ti-V), bem como metavulcânicas máficas a félsicas. Às rochas meta-ígneas, sobrepõem-se metassedimentos detríticos de granulação fina a média, inclusive com pacotes turbidíticos. A partir da composição dos metabasaltos, notadamente, os padrões dos elementos terras raras, concluiu-se que a associação ignea formou-se num ambiente de subdução.

Há muita similaridade entre as rochas do complexo de Brejo Seco, e as da região de Passira, perto da cidade de Recife, PE, que é alvo dos trabalhos da aluna de Doutorado, Ana Cláudia Accioly, orientada do candidato. Em Passira, no entanto, faltam as rochas metavulcânicas e metassedimentares, presentes em Brejo Seco. Além disso, o grau metamórfico em Brejo Seco é mais baixo que em Passira. Há uma faixa notável de complexos semelhantes, todos nas proximidades do lineamento Pernambuco e suas ramificações. A faixa começa perto da borda da bacia do Maranhão, continua até os arredores de Recife, e pode marcar um limte primário de terrenos.

\subsection{Pesquisas sobre granitóides}

A maior atenção sobre o estudo de rochas plutônicas tem sido dada às rochas granitóides, componentes muito importantes de grandes extensões das rochas atualmente expostas no Nordeste e Sudeste do Brasil. 


\subsubsection{Granitóides neoproterozóicos e eocambrianos do Nordeste}

3.2.1.1 Leste do Rio Grande do Norte e Paraíba. $O$ início das pesquisas realizadas sobre granitóides se deu nessa região. As primeiras viagens exploratórias permitiram assinalar a presença de plútons nos arredores das cidades de Japí e Monte das Gabaleiras (RN) e de Dona Inês (PB). As pesquisas preliminares, de mapeamento e de estudos petrográficos (McReath e Perrin, 1979), foram seguidas por estudos mais aprofundados de Monte das Gamaleiras (Galindo, 1982; McMurry, 1982) e Dona Inês (McMurry, 1982). O plúton de Japi foim usado como exemplo de mapeamento e de petrografia de granitóides em aulas práticas da disciplina de Petrologia Ígnea do Curso de Graduação em Geologia da UFRN.

Mais adiante, foram retomadas as pesquisas sobre o plúton de Japí, pois que a fácies alcalina parece represntar manifestação precoce do magmatismo brasiliano associado à zona de cisalhamento na região (Jardim de Sá et al., 1997). Assim, sua posição temporal relativa ao desenvolvimento de uma região orogênica seria contrária à de muitas suites modernas. A contribuição do candidato nesta fase incluiu participação de uma viagem de campo para a verificação geológica e amostragem, a tentativa de datar as fácies, a obtenção e avaliação preliminar de parte dos dados geoquímicos, e participação na orientação da aluna de Mestrado, Maria H. B. M de Holanda.

Outros corpos alcalinos pré ou sin-cisalhamento foram localizados ao longo de zonas de cisalhmento situadas a sul do púton de Japí. O candidato atuou como coorientador da aluna de Mestradoda UFRN, Rielva C. Nascimento, cuja Dissertação constou de um estudo de geoquímica, de química mneral,de geologia isotópica de parte desses corpos.

3.2.1.2 Região do Seridó central. Durante a fase inicial de pesquisas sobre granitóides na UFRN, os pesquisadores Jardim de Sá e Legrand investigaram aspectos estruturais de outras intrusões na região do Seridó. Algumas datações preliminares da região, incluindo-se idades obtidas pelo grupo, permitiram a serparação de gerações com bases estruturais e geocronológicas. As conclusões desse estudo foram apresentadas por Jardim de Sá et al. (1981), e orientaram pesquisas do grupo potiguar durante muito tempo.

O esquema proposto teve um efeito negativo, que é a tendência de identificar granitóides com orientações tectônicas fortes como pertencentes à geração $G_{2}$, de 
iciade transamazônica, quando os mesmos podem ser granitóides pré ou sincolisionais do Brasiliano.

3.2.1.3 Oeste do Rio Grande do Norte. Esta pesquisa originou um projeto de Doutorado na UFPA do Prof. A. C. Galindo da UFRN, sob a orientação do Prof. Dr. R. Dall'Agnol, e com minha coorientação. No início, atraido pela descoberta de faialita num granitóide dentro da cidade de Umarizal, com provável idade brasiliana, o pesquisador Galindo pensou inicialmente em formular um plano de trabalho que dedicava toda sua atenção a este corpo. No entanto, após uma viagem de reconhecimento em companhia dos orientadores e do Prof. Dr. J. M. Sá (UFRN), optou-se por estender a pesquisa, abrangendo os plútons vizinhos. Devido à forma de expressão do magmatismo granítico na região, um "mar de granitos" pois mais de $76 \%$ da área aflorante é constituido por granitos, houve dificuldades na delimitação da área,. optando finalmente pelo inclusão de seis corpos associados a zonas de cisalhamento de escala regional. A Tese teria inicialmente um caráter de reconhecimento, pois os trabalhos de mapeamento previamente disponiveis haviam caracterizada apenas uma suíte granítica, em vez do complexo granítico descoberto.

Os resultados obtidos por Galindo foram apresentados em 1993, e transformados num artigo inicial (Galindo et al., 1995). Em síntese, identificou-se com base em critérios de campo e de geocronologia pelo método de $\mathrm{Rb}-\mathrm{Sr}$, em rocha total, uma seqüência de intrusão de plútons relacionados à zona de cisalhamento principal, desde os sin-cinemáticos, intrudidos ao redor de $630 \mathrm{Ma}$, até os pós-cinemáticos, ao redor de $545 \mathrm{Ma}$. As suites presentes incluem : (i) suites bi-modais, com dioritos potássicos associados a granodioritos/monzogranitos; (ii) uma suíte shoshonítica a álcali-cálcica, com componente máfico composto por jotunito; (iii) uma suíte alcalina, incluindo-se fácies com faialita sem ferrosilita, e outra com ferrosilita sem faialita (mangeritos e charnockitos); e (iv) suites leucograníticas.

A seguir, o Prof. Dr. C. J. Archanjo liderou uma equipe que investigou a anisotropia da susceptibilidade magnética da fácies Umarizal, portadora de faialita. $O$ ex-aluno de Graduação da UFRN, depois aluno de Pós Graduação do IAG-USP, R. I. F. Trindade, desenvolveu uma pesquisa sobre um dos corpos considerados tardicinemáticos por Galindo et al. (1995). Essas pesquisas, com enfoques sobre mecanismos de intrusão, estimularam a retomada dos trabalhos, agora de cunho mais 
específico, dirigido ao entendimento das condições fisico-quimicas de cristalização dos plútons, bem como a datação precisa dos eventos.

Archanjo et al. (1998) argumentaram que a intrusão do corpo composto pela fácies portadora de faialita é um sill que ocupa uma cavidade formado em conseqüência de movimentos tardios de extensão. Trindade et al. (1997) demonstraram que um plúton considerado por Galindo et al. (1995) como tardicinemático com base em critérios estruturais foi, na verdade, sin-cinemático. Em discussões com os outros pesquisadores, foi debatida a possibildade que o magma ascendeu através de uma fratura dilatacional do tipo Riedel, desenvolvida em decorrência dos movimentos maiores da zona de cisalhamento principal. Após ascensão através da fratura extensional, para ocupar a sua posição atual o magma sofreu um processo de expansão essencialmente lateral, aproveitando talvez a descontinuidade entre gnaisses do embasamento e da cobertura metassedimentar.

Subsequentemente, datações $\mathrm{U} / \mathrm{Pb}$ (zircão e titanita) para duas intrusões obtidas por Trindade et al. (1999) mostraram que o granito mais antigo é mais novo do que a idade obtida pela isócrona $\mathrm{Rb} / \mathrm{Sr}$ em rocha total, reduzindo sua idade de $\sim 630 \mathrm{Ma}$ para $\sim 580 \mathrm{Ma}$. Uma reavaliação dos dados referentes às razões ${ }^{87} \mathrm{Sr} /{ }^{86} \mathrm{Sr}$ calculadas para $580 \mathrm{Ma}$ demonstram que o sistema $\mathrm{Rb}-\mathrm{Sr}$ foi afetado pelo processo de mistura de magmas. As idades $\mathrm{U}-\mathrm{Pb}$ (zircão) e $\mathrm{Rb}-\mathrm{Sr}$ (rocha total) para o segundo plúton são concordantes, e de fato, o sistema $\mathrm{Rb}$-Sr satisfaz a exigência para datação isocrônica bem sucedida.

Da intrusão com faialita, considerada a mais nova, duas frações não magnéticas de cristais com morfologias apropriadas de cristalização a temperaturas > $800^{\circ} \mathrm{C}$ (Pupin, 1981) foram cuidadosamente separadas e examinadas por cátodoluminescência e por microscópio electrônico de varredura com sistema de dispersão de energia, para verificar se os cristais possuem núcleos herdados, para investigar a natureza da zonação dos cristais, e para medir os teores de $\mathrm{HfO}_{2}$ na verificação da provável faixa de temperatura de cristalização dos cristais (Pupin, 1992). Os cristais foram considerados satisfatórios para utilização. As idades U-Pb de $\sim 593 \mathrm{Ma}$ para composições isotópicas essencialmente concordantes, obtidas no CPGeo-USP, sugerem que esta intrusão é a mais antiga dos corpos ígneos datados na região! Este problema permanece sob investigação. A falta de afloramento em áreas criticas, perto da zona de cisalhamento maior, todas recobertas por sedimentos meso-cenozóicos, ou 
por solos, oculta as verdadeiras relações geológicas. Entretanto, a $300-400 \mathrm{~m}$ do suposto traçado da zona de cislahmento, o sill não é deformado.

As pesquisas em andamento incluem tentativas de traçar a evolução petrogenética dos magmas charnockitóides com base na utilização de geotermobarômetros (McReath et al., 2000; e em preparação final), pois a intrusão do magma pode ter ocorrida após longa ascensão dentro da crosta, facilitada pela ação ou pela presença das zonas de cisalhamento.

3.2.1.4 Faixa Sergipana, Bahia-Sergipe. Durante suas pesquisas sobre a evolução da Faixa Sergipana na borda Nordeste do cráton São Francisco, o Prof. Dr. Ian Davison do Departamento de Geologia e Geofísica Aplicada do Instituto de Geociências da UFBA percebeu a possibilidade de estabelecer pelo menos um ponto cronológico na evolução dessa faixa através da datação de granitóides sin- a tarditectônicos que a intrudem. Um tipo importante na Faixa a Leste da Bacia de Tucano é representado pelo plútons de Coronel João Sá e de Nossa Senhora da Glória. Na literatura, havia descrições apenas resumidas destes plútons.

Viagens de reconhecimento dos dois corpos revelaram grande interesse petrogenético pelas zonações faciológicas constatadas nos corpos, bem como pela presença de encraves máficos a félsicas, principalmente na parte central do plúton ao redor da cidade de Coronel João Sá. Além disso, há muitos marcadores de orientações preferenciais desenvolvidas durante a fase de fluxo magmático, bem como outras texturas que resultam da cristalização essencialmente in situ, após a parada do fluxo magmático.

Elaborou-se um projeto de Dissertação de Mestrado, a ser desenvolvido pela aluna de Pós Graduação em Geociências, Joselisa M. Chaves, que passou a fazer parte do projeto do Departamento de Geoquímica da UFBA, sobre "Granitóides da Bahia". Através de colaboração com o Laboratório de Geologia Isotópica da UFPA, foram obtidas análises do sistema $\mathrm{Rb}-\mathrm{Sr}$ em rocha total, complementando-se assim os dados já obtidos por geólogos da CPRM. Foram obtidas, também, análises de elementos maiores e traços, visando complementaros dados já disponiveis.. Os resultados e discussões preliminares foram apresentados por Chaves et al. (1989) e Chaves (1991).

Discussões com o Prof. Dr. A. N. Sial com relação às pesquisas sobre granitóides brasilianos nordestinos estimularam uma reavaliação dos dados já obtidos, 
e a obtenção de novos dados petrográficos sobre os encraves máfico-intermediários microgranulares. Esta reavaliação resultou no artigo de McReath et al. (1998), que identificaram duas populações de rochas com base nas composições isotópicas de $\mathrm{Sr}$. De um modo geral, as populações isotopicamente diferentes incluem rochas similares, petrograficamente. Entretanto, a população mais radiogênica concentra-se numa parte do plúton que inclui as rochas mais félsicas, e que contém poucos encraves máficos. Foi proposto que um componente máfico, derivado da fusão parcial de manto enriquecido em LILE e HFSE, está envolvido na petrogênese, e que a petrogênese foi influenciada pela complexidade do sistema de alimentação magmática.

\subsubsection{Granitóides neoproterozóicos do Sudeste brasileiro}

Essas pesquisas estão sendo realizadas em colaboração com os pesquisadores R. Machado (USP) e grupo, e J. C. Mendes (UFRJ. A primeira pesquisa está sendo desenvolvida sobre a geoquímica de gerações de granitóides brasilianos do Rio de Janeiro, enquanto a segunda enfoca padrões dos elementos LILE e HFSE, e de isótopos de $\mathrm{Sr}$ e $\mathrm{Nd}$ em charnockitóides brasilianos de dois plútons no Espírito Santo.

\subsubsection{Granitóides paleoproterozóicos e mesoproterozóicos da Bahia}

3.2.3.1 Embasamento do cinturão de xistos verdes do Rio Itapicuru. Mapeamentos efetuados pela CPRM permitiram separar granitóides não deformados em meio de gnaisses e migmatitos, supostamente arqueanos a (paleo)proterozóicos. Datações U-Pb em zircão (Gaal et al. 1987) demonstraram a idade transamazônica de alguns dos "gnaisses". Observações feitas durante trabalhos de reconhecimento regional realizados pelo grupo de pesquisadores do projeto "Granitóides da Bahia", por outro lado, mostraram que parte dos "migmatitos" - inclusive, o "gnaisse" datado corresponde na realidade a granitos deformados, colocados de maneira sincrônica a movimentos das zonas de cisalhamento regionais. Outras observações permitiram a identificação de várias intrusões, agrupadas de acordo com critérios estruturais em tipos tardi e pós-tectônicos. A região passou a ser um dos alvos principais do projeto "Granitóides da Bahia". O candidato responsibilizou-se no início do projeto pelo mapeamento em escala de semi-detalhe de uma área a sul do Rio Itapicuru, enquanto - Prof. Dr. P. Sabaté dedicou-se às pesquisas petro-estruturais. Os resultados dessas 
pesquisas preliminares foram relatados por Silva et al. (1984a, b), Sabaté et al. (1987) e McReath et al. (1988).

Os critérios estruturais utilizados incluiram: (i) a análise dos estilos de deformação de veios intrudidos sequencialmente num corpo granítico enquanto ele sofria deformações; e (ii) o estilo micro-estrutural da deformação de orientações minerais por zonas de cisalhamento pequenas desenvolvidas em rochas incompletamente solidificadas, em que boa parte dos minerais anísotrópicos, especialmente a biotita, sofreu deflexões progressivas de suas orientações, sem o desenvolvimento de deformações como kink bands ou quebras. Foram caracterizados:

(i) Os corpos sin-tectônicos em relação a movimentos ocorridos ao longo das zonas de cisalhamento regionais que foram intrudidos no estado magmático, e subsequentemente comprimidos ou achatados nos estados visco-plástico a rúptil, conforme atestado por estudos inéditos de Sabaté das morfologias e da orientação de fenocristais e fenoblastos de feldspatos. As orientações internas dos corpos concordam com as orientações regionais das rochas hospedeiras.

(ii) Os corpos tardi-tectônicos foram intrudidos sob condições que conduziram ao desenvolvimento de fortíssimas orientações preferenciais magmáticas. De um modo geral, estas orientações magmáticas concordam com as orienta;cões regionais. Houve superposição de orientações tectônicas, desenvolvidas no estado sólido, apenas em zonas localizadas.

(iii) Os corpos pós-tectônicos geralmente apresentam fortes orientações magmáticas apenas localmente, por exemplo, nas vizinhanças de condutos alimentadores. As orientações, quando presentes, discordam das estruturas regionais. Em alguns casos, é possível identificar planos de orientações, desenvolvidos no estado magmático, que serviram de condutos para a percolação dos fluídos gerados durante as fases tardi e pós-magmática.

As associações ígneas evoluiram, partindo de uma associação bimodal (máficafélsica) nos plútons sin-tectônicos. Nesta associação, o componente máfico ocorre predominantemente como diques sin-plutônicos, deformados juntos aos granitos hospedeiros. Há exemplos em que o dique, incompletamente consolidado, ficou dispersado como uma nuvem de cristais máficos, dentro do granito. As composiçōes químicas são toleiitica a transicional, esta com enriquecimento dos elementos álcalinos. A parte félsica é mais complexa. Um dos componentes félsicos é 
monzonítico a monzogranítico, transicional entre cálcio-alcalino e álcali-cálcico, enquanto o outro é cálcio-alcalino, granodiorítico.

Há outra associação bimodal, máfica-félsica, que ocorre num pluton tarditectônico que foi investigado detalhadamente. Neste plúton, o componente máfico é representado por enxames de encraves, apenas. Os encraves incluem tipos cumuláticos e microgranulares, com aspectos que acusam os efeitos de mistura de magmas (Nascimento \& Sabaté, 1996). Investigações isotópicas revelaram uma situação bastante complexa (Sabaté et al. 1990). O componente félsico é quartzomonzonítico/ quartzo-sienítico a monzogranítico/sienogranítico. A mesma associação, sem os encraves cumuláticos, é presente num outro corpo, de exposição muito pobre e, conseqüentemente, pouco estudado.

Há duas associações nos plútons pós-tectônicos. Uma é essencialmente félsica composta por monzogranitos cinzentos. A segunda associação é alcalina, bimodal, e contém lamprófiros (Conceição et al., 1995).

3.2.3.2 Cinturão chamockitico na margem norte do Complexo Jequié, BA. Estimulado pela paisagem exótica vista da estrada BR-116 no trecho entre o Rio ltapicuru e a cidade de Milagres, o candidato iníciou uma pesquisa sobre os gnaisses e granitóides neste cinturão, que contorna a borda norte do Complexo Jequié e vai de encontro com o cinturão granítico Flamengo-Vitória da Conquista (ver 3.2.3.3 a seguir). Em mapas da CPRM, consta a presença de gnaisses granulíticos e de migmatitos. Entretanto, reconhecimento revelou a presença de charnockitos gnaissicos em corpos próximos à estrada. Subsequentemente, detalharam-se algumas áreas desse cinturão entre as cidades de Amargosa e laçu.

Embora os charnockitóides representam alguns dos plútons de maior expressão, não são o único tipo granítico presente. Foram encontrados na região da escarpa da borda norte do Complexo Jequié: (i) hornblenda-biotita quartzo-monzonito a monzogranito profirítico, recortado por veio e diques pegmatíticos; (ii) leucogranitos com ou magnetita, ou biotita \pm moscovita, ou granada como minerais varietais. A variação mineralógica constatada talvez resulte de variações da pressão parcial d'água e do oxigênio durante a cristalização; e (iii) aplitos extremamente pobres em minerais escuros.

3.2.3.3 Cinturão granítico de Flamengo a Vitória da Conquista, Centro-Leste da Bahia. Depois de participar do reconhecimento descrito na seção anterior, o aluno de 
Pós Graduação em Geociências, opção Geoquímica, P. C. d'Á. Fernandes, optou por trabalhar sobre um plúton charnockítico que ocorre na área de interseção entre o cinturão charnockítico já citado, e o cinturão granítico Flamenga-Vitória da Conquista, como uma contribuição ao projeto Granitóids da Bahia. Com a chegada do Prof. Dr. G. Giuliani para fazer parte do grupo de docentes/pesquisadores, participante neste projeto, definiu-se como um segundo enfoque importante do trabalho, a mineralização do molibdênio, conhecida há bastante tempo, porém nunca pesquisada a fundo. $\mathrm{Na}$ mesma época, deu-se início a uma cooperação entre o Departamento de Geoquímica da UFBA e o Laboratório de Geologia Isotópica da UFPA, que permitiu a inclusão de uma estudo geocronológico do plúton.

Os resultados principais destes trabalhos forma comunicados na Dissertação de Fernandes (1991), e em várias comuniç̧ões a reuniões nacionais e internacionais (Fernandes et al., 1990, 1992a,b,c, 1993, 1996)

3.2.3.4. Plutônicas da bacia do Rio Paramirim. Esta pesquisa foi citada, brevemente, na seção 2.2.4.1. O seu interesse reside na demonstração da possibilidade de que houve importante plutonismosmo máfico, acompanhando o plutonismo félsico, este de tendência transicional a alcalina, e que apresenta muita coisa em comum com as rochas vulcânicas da região.

\subsection{Conclusões}

O estudo de granitóides apresenta muitas dificuldades, devido à complexidade de muitos dos plútons formados por estas rochas. Estas complexidades abrangem, desde aspectos estruturais (internos e externos) dos corpos até suas composições isotópicas. O sucesso na aplicação de qualquer ferramenta de estudo resulta apenas quando a evolução plúton ocorreu sob condições que tornam a utilização da ferramenta escolhida, válida. Assim, por exemplo: não é muito útil usar determinado geotermobarômetro que se reajusta facilmente em decorrência do resfriamento lento do corpo, para deterimnar as condições de cristalização inicial dos minerais precoces. É inútil aplicar um geotermômetro cuja base é a saturação do magma em determinado magma, quando a saturação neste componoente não foi alcançada no magma estudado.

Por outro lado, com a utilização de ferramentas adequadas a cada caso, podese chegar a conclusões interessantes. Ao mesmo tempo, é bom lembrar que estas 
conclusões pode permanecer válidas apenas até a obtenção de novos resultados por outros métodos de estudo!

\subsection{Referências bibliográficas}

ARCHANJO, C. J.; MACEDO, J. W.; GALINDO, A.C. \& ARAÚJO, M. G. S., 1998. Brasiliano crustal extension and emplacement fabrics of the mangeritecharnockite pluton of Umarizal, North-east Brazil. Precamb. Res., 87: 19-32

BASEI, M. A. S.; McREATH, I \& SIGA Jr., O., 1998. The Santa Catarina granulite complex of Southern Brazil: A review. Gond. Res., 1: 383-391

CHAVES, J. M., 1991. Maciços Cel. João Sá e Glória: Petrologia e geoquímica de granitóides do Domínio Macururé, Faixa Sergipana (NE do Brasil). Dissertação inédita de Mestrado, Universidade Federal da Bahia, Salvador. $153 \mathrm{p}$.

CHAVES ET AL. 1989

CONCEIÇÃO, H.; RIOS, D. R. \& ROSA, M. L. S., 1995. Petrologia da associação sientio-lamprófiro: caso da intrusão de Morro do Afonsa (greenstone belt do Rio Itapicuru, Bahia). Geochim. Brasil., 9: 91-109

FERNANDES, P. C. d'Á., 1991. Geoquimica e mineralizações de molibdênio de granitos e charnockitos transamazônicos, Itaberaba, Bahia. Dissertação inédita de Mestrado da UFBA.

FERNANDES, P. C. d'Á.; McREATH, I. \& LAFON, J.-M., 1990. Uma idade transamazônica para o magmatismo, metamorfismo e deformaçãp na borda norte do núcleo de Jequié (Itaberaba, Bahia). 36 Congr. Bras. Geol., Natal. Anais.

FERNANDES, P. C. d'Á., GIULIANI, G. \& McREATH, I., 1992a. Metamorfismo de alto grau e anatexia no limite norte do Núcleo Jequié, Itaberaba, Bahia. 1 Simp. Regional Geol. Bahia-Sergipe, Anais, pp 101-104

FERNANDES, P. C. d"A., GIULIANI, G. \& McREATH, I., 1992b. O distrito uranomolibdenífero transamazônico de Itaberaba, Bahia. 1 Simp. Regional Geol. Bahia-Sergipe, Anais, pp 141-143 
FERNANDES, P. C. d'Á., McREATH, I. \& GIULIANI, G., 1992c. O maciço transamazônico de Pedra d'Água (Itaberaba, Bahia): um charnockito peraluminoso de fonte crustal. 1 Simp. Regional Geol. Bahia-Sergipe, Anais, pp. $155-159$

FERNANDES, P. C. d'Á., McREATH, I. \& GIULIANI, G., 1993. Petrogenesis and Mo, W mineralizations in early Proterozoic charnokites and granites from the Itaberaba district (Bahia, Brazil). "Workshop"sobre Magmatismo e Mineralizações, Acad. Bras. Cien., Resumsos, pp. 62-65

FERNANDES, P. C. d'Á., McREATH, I. \& GIULIANI, G., 1996. Uranium and molybdenum mineralization of early Proterozoic charnockites and granites of Itaberaba, Bahia, Brazil. GAC/MAC Joint Meeting, Winnepeg. Program Absts.,p. A-29

FIGUEIREDO, M. C. H.; McREATH, I.; BASEI, M. A. S. \& MANTOVANI, M. S. M., 1997. Geochemistry of Santo Catarina granulite rocks, Southern Brazil: A model of differentiation from high alumina basalt. Rev. Bras. Geoc., 27: 33-40

GAAL, G.; TEIXEIRA, J. B. G.; DEL REY, J. M. H. \& SILVA, M. G. da, 1987. New U-Pb data from granitoids reflecting early Proterozoic evolution in Northeast BahiaBrazil. In: I Internat. Symp. Granites Assoc. Mineraliz., Salvador. Extended Abstracts. (Obs.: O segndo autor gentilmente cedeu cópia da versão preliminar do relatório inédito, usado de base para este reumo, que foi comunicado, más não publicado).

GALINDO, A. C., 1982. Estudo petrológico do cropo granítico de Monte das Gamaleiras - RN/PB. Dissertação inédita de Mestrado, Universidade Federal de Pernambuco, Recife.

GALINDO, A. C., 1993. Petrologia dos granitóides brasilianos da região de Caraúbas Umarizal, Oeste do Rio Grande do Norte. Tese inéwdita de Doutorado, Universidade Federal do Pará, Belém. 319 pp.

GALINDO, A. C.; DALL'AGNOL, R. ; MCREATH, I.; LAFON, J.-M. \& TEIXEIRA, N., 1995: Evolution of Brasiliano-age granitoid types in a shear zone environment, Umarizal-Caraúbas region, RioGrande do Norte, Northeast Brazil. Jour. South Amer. Earth Sci., 8: 79-95 
JARDIM DE SÁ, E. F.; LEGRAND, J.-M. \& MCREATH, I., 1981. "Estratigrafia" de rochas granitóides ma região do Seridó (RN-PB) com base em critérios estruturais. Rev. Bras. Geoc., 11: $50-57$

JARDIM DE SÁ, E. F. et al., 1997. Syntectonic alkalic granites emplaced in a Brasiliano-age strikeslip/extensional setting (eastern Seridó belt, NE Brazil). In: 11 Internat. Symp. Granites Assoc. Mineraliz., Salvador. Extended Abstract Program, pp. 310-312

MARIMON, M. P. C., 1990. Petrologia e litogeoquimica da seqüência vulcanossedimentar de Brejo Seco, Município de São João do Piauí, Estado do Paiui. Dissertação nédita de Mestrado, Universidade Federal da Bahia.

MCMURRY, J., 1982. Petrology and Rb-Sr geochemistry of Monte das Gamaleiras and Dona Inês plutons, northeastern Brazil. Tese inédita de Mestrado, Universidade de Texas, Austin. $180 \mathrm{pp}$.

MCREATH, 1., 1963. The determnation of strontium and barium in the rocks of the Skaergaard Intrusion by X-ray fluorscence analysis. Relatório inédito de Graduação, Universidade de Oxfor, Inaglaterra.

McREATH, I., 1985. Magmatismo intracratônico proterozócio da bacia do Rio Paramirim. "Workshop", Granitogênese e Mineralizações Associadas, NEG/CNPq, Caruaru, PE, Resumos.

MCREATH. 1. \& PERRIN, P., 1979. Corpos circulares e sub-circulares na área divisória dos Estados do Rio Grande do Norte e da Paraiba. In: IX Simp. Geol. Nordeste (Natal). Bol. No. 7 (Atas): p. 52-55

McREATH, I. \& SABATÉ, P., 1987. Granitoids of the State of Bahia: a review. Rev. Bras. Geoc., 17: 404-414

McREATH, I; SABATÉ, P. \& MASCAREMHAS, O. M., 1988. Granitóides sintectônicos transamazônicos nos terrenos de médio-alto grau a oeste do "greenstone belt" do Rio Itapicuru-BA. VII Congr. Latino-Americano Geol., Belém. Atas, V. 1: p. 560-566.

McREATH, I.; LAFON, J.-M.; DAVISON, I.; CHAVES, J. M. \& CONCEIÇÃO, H., 1998. Late tectonic Brasiliano-age granitoids in the Sergipana fold belt: The Coronel João Sá pluton and its implications. Jour. Sth. Amer. Earth Sci., 11: 51-66 
MCREATH, I.; GALINDO, A. C. \& DALL'AGNOL, R., 2000. The Neoproterozoic Umarizal Igneous Association, NE Brazil, and the implications for the genesis of A-type granites Resumo aceito para apresentação ao IGC, Rio de Janeiro.

NASCIMENTO, H. A. de, \& SABATÉ, PO., 1996. Significado dos encraves máficos numa intrusão monzonítica, Bahia, Brasil. In; 39 Congr. Bras. Geol., Salvador. Resumos Vol. 2.

PUPIN, J.-P., 1981. Zircon and granite petrology. Contrib. Mineral. Petrol.,73: 207-220

PUPIN, J.-P.,1992. Les zircons des granites océaniques et continentaux: coplage typologie-géochimie des eléments en traces. Bull. Soc. géol. France, 163: 485507

SABATÉ, P. McREATH, I. \& GIULIANI, G., 1987. Plutonic associations of Northeast Bahia. Int. Simp. Granites Associated Mineralizations, Salvador. Excursion Guides, p. $91-122$

SABATÉ, P.; CAEN-VACHETTE, M.; MARINHO, M. M.; VIDAL, Ph \& SOARES FILHO, C. P., 1990. Dados isotópicos Rb-Sr e Sm-Nd da intrusão monzonítica a 2,0 Ga de Cansanção (Bahia, Brasil), implicações sobre as fontes. In: 36 Congr. Bras. Geol., Natal. Bol. Resumos, p. 163

SILVA, G. V. M. da, McREATH, I. \& SABATÉ, P., 1984A. Granitóides da Bahia a leste do Rio São Francisco. 11 Simp. Geol. Nordeste, Natal. Resumos.

SILVA, G. V. M.; SABATÉ, P. \& McREATH, I., 1984b. Granitóides transamazônicos da Bahia: tendências petrológicas e relações geotectônicas. 33 Congr. Bras. Geol, Rio de Janeiro. Resumos

TRINDADE. R. I.F; ERNESTO, M.; ARCHANJO, C. J. \& USSAMI, N., 1997. Emplacement of flattening-plane oriented plutons 9n shear sones: the case opf the Tourão maddif (western Seridó belt, NE Brazil). Ii Inter. Symp. Granites Assoc. Mineralizations, Salvador.Extended Abst. Program, pp.327-328

TRINDADE, R. I. F.; DANTAS, E. L.; BABINSKI, M. \& VAN SCHMUS, W> R., 1999. Short-lived granite magmatism along shear zones: Evidence from U-Pb zircon and sphene ages of Caraubas and Tourão granites. In: II. Simp. Sul. Amer. Geol. Isot., Córdoba, Argentina. Actas, p. 143-144

WAGER, L. R. \& BROWN, G.M., 1967. Layered Igneous Rocks. Freeman, São Francisco. 


\title{
CAPÍTULO 4: ANÁLISE DE ROCHAS E MINERAIS
}

\author{
"Nunca saberemos a verdadeira concentração \\ de qualquer elemento nesses padrões" (Fairbairn 1951)
}

\subsection{Comentários preliminares}

Antes da primeira guerra mundial todas as análises químicas eram feitas por via úmida aproveitando-se, principalmente, de procedimentos gravimétricos. Em muitos casos, o teor de $\mathrm{Al}_{2} \mathrm{O}_{3}$ era determinado por diferença, por não haver outra opção satisfatória. Os álcalis eram determinados por métodos gravimétricos por procedimentos que exigiam extremo cuidado por parte do analista. Era comum, entretanto, aplicar rigor no controle de qualidade, fazendo-se duplicatas e controlando o somatório dos óxidos dentro de limites rígidos. Manteve-se essa rigidez nas análises obtidas até logo depois da segunda guerra mundial, num período em que os métodos instrumentais (colorimetria, espetrofotômetria) começaram a ser usados.

A partir do fim da segunda guerra mundial, houveram vários avanços na química analítica. Um avanço importante no que se diz respeito à determinação dos elementos-traço foi dado através da aplicação de espectrografia de emissão de arco de corrente contínuo (EE; ver, por exemplo, Nockolds e Allen, 1953). De um modo geral, EE permitia a determinação das concentrações de muitos elementos na faixa de 10-1000 p.p.m. As limitações principais são a estabilidade do arco durante cada análise, e de análise para análise, bem como pela a reprodução exata das condições da revelação das placas espectrográficas, e da leitura das densidades das imagens das linhas de emissão registradas pelas placas. Além disso, questiona-se se as pequenas quantidades de amostra usadas (geralmente, $<100 \mathrm{mg}$ ) representam a amostra coletada no campo. Há grandes problemas com a determinação daqueles elementos, presentes em traços na rocha, que se concentram em minerais acessórios, como é o caso, por exemplo, do zircônio, concentrado pelo zircão.

Este avanço na obtenção das concentrações dos elementos em traços se deu na mesma época em que ampliou-se a utilização de métodos colorimétricos e espectrofotométricos na determinação de alguns elementos maiores. Ao mesmo tempo, começou-se o controle da qualidade das análises através dos programas comparativos de análises de padrões internacionais, com a distribuição dos dois primeiros padrões, o granito G1 e o diabásio W1, pelo Serviço Geológico dos Estados 
Unidos. No início, os resultados eram, ao mesmo tempo, desanimadores e encorajadores (Fairburn et al., 1951). Desanimadores, porque alguns laboratórios conseguiram resultados muito longes dos obtidos por outros laboratórios. Encorajadores, porque laboratórios bem conceituados produziram resultados bastante semelhantes.

$\mathrm{Na}$ análise química de rochas e minerais, os anos 60 caraterizaram-se pela difusão dos métodos de espectrometria de fluorescência de raios-X (EFRx) e de espectrofotometria de absorção atômica (EAA) na determinação de elementos maiores e em traços. Com a introdução dos discos fundidos, eliminam-se ou reduzem-se ao mínimo os efeitos de matriz, muito complexos em rochas. Permite-se, portanto, aproveitar as caraterísticas da EFRx, conhecidas desde a década anterior, que favorecem a obtenção de resultados precisos, tanto para os elementos maiores, usando-se curtos tempos de contagens, como para os elementos em traços, através do ajuste para maior do tempo de contagem.

McReath (1972) estendeu o método do disco fundido para analisar pequenas quantidades $(<200 \mathrm{mg})$ de minerais puros, separados por meios físicos, com éxito. De um modo geral, os resultados concordaram com os obtidos por microssonda eletrônica, com determinações ópticas de minerais como a olivina magnesiana e o plagioclásio cálcico, e com análises de outras alíquitas das mesmas amostras.

Nessa época também, a EAA passa pelo ciclo, comum a praticamente todos os métodos instrumentais novos: (i) divulgação pelos descobridores/desenvolvidores dos princípios do método, e de alguns resultados (geraimente, suficientemente impressionantes para chamar a atenção) obtidos em equipamentos experimentais; (ii) lançamento dos primeiros equipamentos comerciais (no caso aqui discutido, adaptações de outros equipamentos já existentes); (iii) fase de deçepção do usuário comum, aliada ao descobrimento e à solução pelo menos parcial, de alguns problemas fundamentais; (iv) lançamento da segunda geração de equipamentos, e aplicação crescente do método em análises de materiais geológicos, devido a sua sensibilidade na deteção e na medição de uma ampla gama de elementos, usando-se preparações das amostras mais adequadas, e tratamento computadorizado dos dados de instensidade crus, para compensar efeitos de matriz, etc.

Nessa década, foi distribuída a segunda série de padrões internacionais do USGS (Flanagan 1969). A seguir, a busca de métodos cada vez mais seinsiveis 
resulta na introdução de espectrometria de emissão óptica com fonte de plasma com acomplamento indutivo (EEA-PAI) e, na década atual, espectrometria de massas com fonte de plasma (EM -PAI). A lista de elementos determinados cresce, dos 20-25 reportados nos anos 60 aos 45-50 elementos nos dias atuais, enquanto os limites de deteção decrescem sucesivamente até, em alguns casos, a casa de akgumas partes por bilhão.

\subsection{Verificações dos desempenhos de métodos de rotina}

A Tabela 4.1 apresenta uma compilação de resultados selecionados referentes ao padrão G1. Nota-se que os resultados obtidos pelos melhores laboratórios em 1960 através dos métodos então disponiveis (via úmida, EEA, etc.) são, na sua maioria, indistinguiveis do obtidos pelos métodos mais novos. Estes, entretanto, deixam um maior número de elementos ao alcance do geoquímico.

A Tabela 4.2 apresenta dados obtidos por uma combinação de EFRx e EEA, principalmente, no ínicio da década de 70 pelo autor e outros pesquisadores, bem como os valores recomendados naquele tempo e hoje, para os padrões AGV-1 (andesito) e BCR-1 (basalto). É provável que o performance alcançado represente o performance típico dos bons laboratórios analíticos da época.

Finalmente, a Tabela 4.3 reporta valores obtidos durante os últimos três anos, por EFRx e EEA-PAI nos laboratórios do DMP/IGc-USP pelo autor e outros pesquisadores para alguns padrões distribuidos durante as décadas de 70 e 80 . E possivel verificar que, para muitos elementos, os valores obtidos pelos pesquisadores do IGc-USP são praticamente indistingüíveis dos valores

recomendados, levadas em conta as precisões vigentes. Há, é claro, espaço para melhorias, que podem resultar: (i) da utilização de discos funđidas para a determinação de $\mathrm{SiO}_{2}$ e $\mathrm{Al}_{2} \mathrm{O}_{3}$ por EFRx; (ii) da homogeneização mais eficiente da amostra em pó e ligante na preparação das pastilhas prensadas; e (iii) na separação de calibrações especificas para rochas ultramáficas/máficas, intermediárias e félsicas, combinada ao aumento do tempo de contagem para aqueles elementos cujas concentrações aproximam-se às do limite de deteção.

Pastilhas prensadas: a partir de amostra em pó "micronisado" durante 20 - 30 min em moinho do tipo McCrone com recipiente de plástico, elementos de moagem de ágata, em meio etílico. Na prática, a granulação média final gira em torno das 2 - 4 
Tabela 4.1: Valores recomendados para o padrão $\mathrm{G1}$

\begin{tabular}{|l|r|r|r|l|r|r|}
\hline $\begin{array}{l}\text { Óxido ou } \\
\text { elemento }\end{array}$ & \multicolumn{1}{|c|}{$(1)$} & \multicolumn{1}{c|}{$(2)$} & \multicolumn{1}{c|}{$(3)$} & Elemento & \multicolumn{1}{c|}{$(2)$} & \multicolumn{1}{c|}{$(3)$} \\
\hline $\mathrm{SiO}_{2}$ & 72,45 & 72,45 & $72.51(0,19)$ & $\mathrm{F}$ & 730 & $680(70)$ \\
\hline $\mathrm{TiO}_{2}$ & 0,25 & 0,26 & $0,27(0,2)$ & $\mathrm{Ga}$ & & $19,5(1,5)$ \\
\hline $\mathrm{Al}_{2} \mathrm{O}_{3}$ & 14,30 & 14,29 & $14,23(0,21)$ & $\mathrm{In}$ & 0.026 & 0,035 \\
\hline $\mathrm{Fe}_{2} \mathrm{O}_{3}$ & 0,85 & 0,87 & $0,86(0,16)$ & $\mathrm{La}$ & 150 & $105(16)$ \\
\hline $\mathrm{FeO}$ & 1,00 & 0,98 & $0,97(0,07)$ & $\mathrm{Li}$ & 24 & $21,3(0,6)$ \\
\hline $\mathrm{MnO}$ & 0.025 & 0,03 & $0,03(0,01)$ & $\mathrm{Mo}$ & 7 & $6,8(1,7)$ \\
\hline $\mathrm{MgO}$ & 0,45 & 0,41 & $0,36(0,07)$ & $\mathrm{Nb}$ & 20 & $22,6(1,0)$ \\
\hline $\mathrm{CaO}$ & 1,35 & 1,39 & $1,37(0.06)$ & $\mathrm{Ni}$ & & $3,4(1,8)$ \\
\hline $\mathrm{Na}$ & 3.35 & 3,32 & $3,33(0,5)$ & $\mathrm{Pb}$ & & $46(2)$ \\
\hline $\mathrm{K}_{2} \mathrm{O}$ & 5,45 & 5,46 & $5,51(0,06)$ & $\mathrm{Rb}$ & 220 & $214(2)$ \\
\hline $\mathrm{P}_{2} \mathrm{O}_{5}$ & 0,10 & 0,09 & $0.08(0.01)$ & $\mathrm{Sr}$ & $280(250)$ & $248(11)$ \\
\hline & & & & $\mathrm{Ta}$ & & $1,5(0,4)$ \\
\hline $\mathrm{Ba}$ & & 1220 & $1080(60)$ & $\mathrm{Th}$ & 52 & $51(7)$ \\
\hline $\mathrm{Be}$ & & 3,3 & $3,0(0.3)$ & $\mathrm{U}$ & 37 & $3,4(0,5)$ \\
\hline $\mathrm{Ce}$ & & & $173(24)$ & $\mathrm{V}$ & 21 & \\
\hline $\mathrm{Co}$ & & $2,5(2,2)$ & $2,3(0,2)$ & $\mathrm{W}$ & & $0,43(0.04)$ \\
\hline $\mathrm{Cr}$ & & 22 & $20(6)$ & $\mathrm{Y}$ & 21 & $13,0(0,3)$ \\
\hline $\mathrm{Cs}$ & & & $1,6(0,3)$ & $\mathrm{Zn}$ & & $45(8)$ \\
\hline $\mathrm{Cu}$ & & 13 & $12(2)$ & $\mathrm{Zr}$ & $210(185)$ & $201(23)$ \\
\hline
\end{tabular}

Óxidos em \% de peso; elementos em traços, em p.p.m. (1) Fairburn et al. (1951); (2) Stevens et al. (1960); valores de consenso ou recomendados; números em parênteses, valores de arbitragem; (3) Gladney et al. (1991); valores em parênteses, $1 \sigma$ absoluta - para elementos maiores, em \% de peso; para elementos em traços, em p.p.m.

Tabela 4.2: Resultados para os elementos maiores nos padrões AGV-1 e BCR-1

\begin{tabular}{|l|c|c|c|c|c|c|}
\hline & \multicolumn{3}{|c|}{$\mathrm{AGV}-1$} & \multicolumn{3}{c|}{$\mathrm{BCR}-1$} \\
\hline & $(1)$ & $(2)$ & $(3)$ & $(1)$ & $(2)$ & $(3)$ \\
\hline $\mathrm{SiO}_{2}$ & 59,1 & $58,99_{7}$ & $58,84(0,28)$ & 54,1 & $54,48_{5}$ & $54,11(0,28)$ \\
\hline $\mathrm{TiO}_{2}$ & 1,05 & $1,08_{2}$ & $1,05(0,05)$ & 2,32 & $2,23_{4}$ & $2,24(0,10)$ \\
\hline $\mathrm{Al}_{2} \mathrm{O}_{3}$ & 17,0 & $17,01_{4}$ & $17,15(0,15)$ & 13,6 & $13,65_{7}$ & $13,65(0,25)$ \\
\hline $\mathrm{Fe}_{2} \mathrm{O}_{3}$ & 6,71 & $6,80_{4}$ & $6,77(0,17)$ & 13,7 & $13,50_{8}$ & $13,42(0,36)$ \\
\hline $\mathrm{MnO}$ & 0,10 & $0,09_{4}$ & $0,09(0,01)$ & 0,19 & $0,17_{6}$ & $0,18(0,01)$ \\
\hline $\mathrm{MgO}$ & 1,49 & $1,49_{2}$ & $1,53(0,10)$ & 3,49 & 3,28 & $3,48(0,13)$ \\
\hline $\mathrm{CaO}$ & 4,98 & $4,98_{2}$ & $4,94(0,14)$ & 6,99 & $6,95_{2}$ & $6,95(0,15)$ \\
\hline $\mathrm{Na}_{2} \mathrm{O}$ & $(-)$ & $4,33_{4}$ & $4,26(0,11)$ & $(-)$ & $3,31_{3}$ & $3,27(0,12)$ \\
\hline $\mathrm{K}_{2} \mathrm{O}$ & 2,90 & $2,89_{8}$ & $2,92(0,08)$ & 1,78 & $1,68_{4}$ & $1,69(0,04)$ \\
\hline $\mathrm{P}_{2} \mathrm{O}_{5}$ & 0,49 & $0,48_{7}$ & $0,49(0,04)$ & 0,49 & $0,36_{3}$ & $0,36(0,02)$ \\
\hline
\end{tabular}



Tabela 4.2 (cont.): Resultados para elementos
em traços nos padrões AGV-1 e BCR-1

\begin{tabular}{|l|r|r|r|r|r|r|}
\hline & \multicolumn{3}{|c|}{ AGV-1 } & \multicolumn{1}{c|}{ BCR-1 } \\
\hline & $(1)$ & \multicolumn{1}{|c|}{$(2)$} & \multicolumn{1}{c|}{$(3)$} & \multicolumn{1}{c|}{$(1)$} & \multicolumn{1}{c|}{$(2)$} & \multicolumn{1}{c|}{$(3)$} \\
\hline $\mathrm{Ba}$ & & & & 790,872 & 790 & $681(15)$ \\
\hline $\mathrm{Co}$ & & & & $56,(-)$ & 35,5 & $37(2)$ \\
\hline $\mathrm{Cr}$ & & & & $14,(-)$ & 16,3 & $16(4)$ \\
\hline $\mathrm{Li}$ & & & & $19,(-)$ & 16,9 & $12,9(0,4)$ \\
\hline $\mathrm{Ni}$ & $17,5(0,7)$ & 17,8 & $16(3)$ & 16,18 & 15 & $13(4)$ \\
\hline $\mathrm{Rb}$ & $69(7,0)$ & 89,4 & $67,3(0,9)$ & $(-), 46$ & 72,8 & $47,2(0,6)$ \\
\hline $\mathrm{Sr}$ & $657(15,8)$ & 657 & $662(9)$ & 433,348 & 345 & $330(5)$ \\
\hline $\mathrm{V}$ & & & & $418,(-)$ & 384 & $407(34)$ \\
\hline $\mathrm{Y}$ & $18(4)$ & 25,3 & $20(3)$ & $(-), 26$ & 46,2 & $38(5)$ \\
\hline $\mathrm{Zr}$ & $253(25)$ & 227 & $227(18)$ & 185,193 & 185 & $190(6)$ \\
\hline
\end{tabular}

(1) Resultados obtidos por pesquisadores do Departamento de Geociências da Universidade de Leeds; elementos maiores, em disco fundido com sais de Na; elementos em traços; para AGV1, por EFRx; para BCR-1, o primeiro resultado é por EEA (analista, I. McR.), o segundo, por EFRx; as estimativas de precisão foram obtidas por l. McR. em testes de replicação com uma para controle; (2) valores recomendados de Flanagan (1969); (3) valores recomendados precisão, ver Tabela 1.

\section{Tabela 4.3: Resultados analíticos obtidos nos laboratórios do DMP/IGc-USP para padrão JB1a}

\begin{tabular}{|l|r|r|r|r|r|r|r|}
\hline & \multicolumn{1}{|c|}{$(1)$} & \multicolumn{1}{|c|}{$(2)$} & $(3)$ & & \multicolumn{1}{|c|}{$(1)$} & \multicolumn{1}{|c|}{$(2)$} & $(3)$ \\
\hline $\mathrm{SiO}_{2}$ & 52,16 & 52,63 & 51,45 & $\mathrm{~F}$ & & & 15 \\
\hline $\mathrm{TiO}_{2}$ & 1.3 & & 1,264 & $\mathrm{Ga}$ & 18 & & 57 \\
\hline $\mathrm{Al}_{2} \mathrm{O}_{3}$ & 14,51 & 14,26 & 14,07 & $\mathrm{La}$ & $37,8(2,5)$ & $31,7(3,1)$ & 31 \\
\hline $\mathrm{Fe}_{2} \mathrm{O}_{3}$ & 9,10 & 9,05 & 9,11 & $\mathrm{Nb}$ & 27 & & 24 \\
\hline $\mathrm{MnO}$ & 0,15 & & 0,146 & $\mathrm{Nd}$ & 25,5 & & 138 \\
\hline $\mathrm{MgO}$ & 7,75 & 7,94 & 7,64 & $\mathrm{Ni}$ & $139(15)$ & $124(4)$ & 5 \\
\hline $\mathrm{CaO}$ & 9,23 & 9,23 & 9,29 & $\mathrm{~Pb}$ & 7,2 & & 37 \\
\hline $\mathrm{Na}_{2} \mathrm{O}$ & 2,73 & 2,75 & 2,68 & $\mathrm{Rb}$ & 41 & & 28 \\
\hline $\mathrm{K}_{2} \mathrm{O}$ & 1,42 & 1,43 & 1,43 & $\mathrm{Sc}$ & $27,8(3,7)$ & & 420 \\
\hline $\mathrm{P}_{2} \mathrm{O}_{5}$ & 0,26 & & 0,251 & $\mathrm{Sr}$ & 443 & & 11 \\
\hline & & & & $\mathrm{Th}$ & 8,8 & & 1 \\
\hline $\mathrm{Ba}$ & 497 & & 552 & $\mathrm{U}$ & 1,6 & & 203 \\
\hline $\mathrm{Ce}$ & 66,1 & & 78 & $\mathrm{~V}$ & $204(16)$ & 213 & 31 \\
\hline $\mathrm{Co}$ & $38,6(4,2)$ & $41,0(2,2)$ & 40 & $\mathrm{Y}$ & $34(2,5)$ & $20,0(1,0)$ & 75 \\
\hline $\mathrm{Cr}$ & 415 & & 406 & $\mathrm{Zn}$ & $82,1(5)$ & $87,7(2,9)$ & 151 \\
\hline $\mathrm{Cu}$ & $56,7(3,6)$ & $51,3(1,5)$ & 81 & $\mathrm{Zr}$ & 146 & & \\
\hline
\end{tabular}

(1) valores recomendados por REFS; (valores por EEA-PAI, elementos maiores após fusão obtidos por $V$ de $A$. Janassi, elementos em traços após digestão ácida por I. McReath, valores em parênteses, deviso padrão absoluto; (2) valores recomendados e, em parênteses, desvio padrao absoluto; (3) valores for FRx em pastilhas presenadas 
micras. Após secagem, o pó é prensado em suporte de ácido bórico com aglutinante de álcool polivinílico $3 \%$ em meio aquoso.

As curvas de calibração são estabelecidas através da utilização de amostraspadrão internacionais. Estimaram-se os limites de deteção para os elementos-traço como a concentração do elemento analisado ( $c$ p.p.m.) necessária para produzir uma taxa de contagem de $1_{\text {fundo }}+3 \sigma_{\text {ffundo, }}$ onde $I_{\text {fundo }}=$ iontensidade do ruído de fundo no coprimento de onda do elemento determinado.. Na prática, alcançam-se precisões relativas de $\pm 50 \%$ apenas quando a concentração do elemento presente c fica na casa de 2 - 3.c, enquanto alcançam-se precisões relativas da ordem de $\pm 5 \%$ apenas quando $c=5-10 . c$. O controle de qualidade é feito (i) através da utilzação de padrões internacionais como desconhecidas; e (ii) através de duplicatas aleatórias de amostras desconhecidas. Foram usados seis padrões internacionais (duas máficas e quatro félsicas) para avaliar a exatidão das análises, a partir do cálculo da divergência relativa média $D=100 . \Sigma\left|\left(x_{\text {med }}-x_{\text {rec }}\right)\right| / n$. $x_{\text {rec, }}$ onde $x_{\text {med }}=$ concentração medida do elemento $x$; $x_{\text {rec }}=$ concentração recomendada; $n=$ número de padrões usados no cálculo. Consideram-se as análises das đuplicatas satisfatórias, quando 100. $\left(x_{i}-x\right) / x \leq D$.

De um modo geral, resultados para os componentes $\mathrm{SiO}_{2}$ e, especialmente, para $\mathrm{Al}_{2} \mathrm{O}_{3}$ säo insatisfatórios, havendo uma tendência para viés negativos que resultam em baixos somatórios, inferiores a $98 \%$ e, muitas vezes, inferiores a $95 \%$. Análises dos componentes $\mathrm{TiO}_{2}, \mathrm{Fe}_{2} \mathrm{O}_{3}$ (tot), $\mathrm{MnO}, \mathrm{CaO}, \mathrm{Na}_{2} \mathrm{O}$ e $\mathrm{K}_{2} \mathrm{O}$ são satisfatórios, com valores de $D$ na faixa $\pm 2,0 \%- \pm 3,3 \%$. Para $\mathrm{MgO}$ e $\mathrm{P}_{2} \mathrm{O}_{5}$, os valores de $D$ são \pm $7,8 \%$ e $\pm 8,7 \%$, respeitivamente.

Foram estabelecidas calibrações para 23 elementos-traço. $\mathrm{Na}$ prática, resultados satisfatórios (com $D<10 \%$ ) foram obtidos para concentrações iguais ou superiores aos respectivos limites de deteção, em rochas tanto máficos como félsicas, para apenas sete desses elementos. Bons resultados foram obtidos para $\mathrm{Ni}$ apenas em rochas máficas, enquanto os resultados para outros elementos ( $\mathrm{Nb}, \mathrm{La}, \mathrm{Ce}, \mathrm{Nd}$ ) foram de boa qualidade apenas em rochas félsicas. Nenhum resultado de confiança foi obtido para os elementos $\mathrm{Th}, \mathrm{U}, \mathrm{Cl} \ldots$ 
Tabela 4.4: Avaliação do performance

de E. F. R-x no IGc-USP em 1998-9

\begin{tabular}{|c|c|c|c|c|}
\hline $\begin{array}{l}\text { Componente } \\
\text { e método (a) }\end{array}$ & $\begin{array}{c}c \\
\text { p.p.m. } \\
\text { (b) }\end{array}$ & $\begin{array}{l}D \% \\
\text { (c) }\end{array}$ & $\begin{array}{c}\mathrm{N}^{\circ} . \text { e tipo } \\
\text { de } \\
\text { padrão (d) }\end{array}$ & $\begin{array}{l}\text { Faixa de } \\
\text { conc. } \\
\text { p.p.m. (e) }\end{array}$ \\
\hline $\begin{array}{r}\mathrm{SiO}_{2}(1) \\
(2) \\
\end{array}$ & & $\begin{array}{l}0,9 \\
0,1 \\
\end{array}$ & $\begin{array}{c}6(\mathrm{MF}) \\
1(\mathrm{M}) \\
\end{array}$ & \\
\hline $\mathrm{TiO}_{2}(1)$ & & 3,5 & $6(\mathrm{MF})$ & \\
\hline $\begin{array}{r}\mathrm{Al}_{2} \mathrm{O}_{3}(1) \\
(2) \\
\end{array}$ & & $\begin{array}{l}2,7 \\
0,1\end{array}$ & $\begin{array}{c}6(\mathrm{MF}) \\
1(\mathrm{M})\end{array}$ & \\
\hline $\mathrm{Fe}_{2} \mathrm{O}_{3}(\mathrm{tot})(1)$ & & 3,3 & 6(MF) & \\
\hline $\mathrm{MnO}(1)$ & & 2,0 & $6(\mathrm{MF})$ & \\
\hline $\begin{array}{r}\mathrm{MgO}(1) \\
(2) \\
\end{array}$ & & $\begin{array}{l}7,8 \\
0,5 \\
\end{array}$ & $\begin{array}{l}6(\mathrm{MF}) \\
1(\mathrm{M})\end{array}$ & \\
\hline $\mathrm{CaO}(1)$ & & 2,1 & $6(\mathrm{MF})$ & \\
\hline $\mathrm{Na}_{2} \mathrm{O}(1)$ & & 3,1 & 6(MF) & \\
\hline $\mathrm{K}_{2} \mathrm{O}(1)$ & & 2,0 & $6(\mathrm{MF})$ & \\
\hline $\mathrm{P}_{2} \mathrm{O}_{5}(1)$ & & 8,7 & $6(\mathrm{MF})$ & \\
\hline $\mathrm{Ni}(1)$ & 10 & 2,8 & $1(\mathrm{M})$ & 142 \\
\hline Co (1) & 10 & 4,1 & $4(\mathrm{MF})$ & $12-62$ \\
\hline $\mathrm{Cr}(1)$ & 10 & 20.1 & $3(\mathrm{MF})$ & $60-418$ \\
\hline$V(1)$ & 10 & 8,3 & $5(\mathrm{MF})$ & $166-323$ \\
\hline $\mathrm{Rb}(1)$ & 10 & 4,3 & $4(\mathrm{MF})$ & $41-182$ \\
\hline $\mathrm{Sr}(1)$ & 10 & 3,5 & $5(\mathrm{MF})$ & $166-323$ \\
\hline $\mathrm{Ba}(1)$ & 20 & 6,7 & 5(MF) & $55-849$ \\
\hline $\mathrm{Ga}(1)$ & 7.5 & 14,4 & $6(\mathrm{MF})$ & \\
\hline Sc (1) & 10 & 4,1 & $3(\mathrm{MF})$ & $27-37$ \\
\hline$Y(1)$ & 10 & 25,2 & 4(MF) & $21-186$ \\
\hline $\mathrm{La}(1)$ & 10 & 18,2 & 4(MF) & $22-59,5$ \\
\hline $\mathrm{Ce}(1)$ & 20 & 12,7 & 4(MF) & $45,6-155,3$ \\
\hline $\mathrm{Nd}$ & 10 & 12,2 & $4(\mathrm{MF})$ & $21,2-92.8$ \\
\hline $\mathrm{Zr}(1)$ & 10 & 9,9 & $5(\mathrm{MF})$ & $89-787$ \\
\hline $\mathrm{Nb}(1)$ & 15 & 10,0 & 2(MF) & $27,3-110,9$ \\
\hline$F(1)$ & 150 & 13,8 & $4(\mathrm{MF})$ & $454-2118$ \\
\hline
\end{tabular}

Anotações para a Tabela 4.4:

(a) (1) = pastilha prensada; (2) = pastilha fundida.

(b) estimativa do limite de deteção (ver texto): para elementos maiores, \% em peso; para elementos-traço, p.p.m.

(c) desvio relativo (ver texto)

(d) tipo de amostra-padrão: $M=$ máfico; $F=$ félsico; $M F=$ máfico a félsico.

(e) faixa de concentrações nas amostras-padrão 
Aiguns métodos, tais como activação neutrônica (AN) por reator nuclear ou por isótopos, ou de diluição isotópica por espectrometria de massas com fonte sólida (DI), mantêm, ainda, sua pequena penetração na análise dos elementos. Entretanto, demonstram suas vantagens de elevada sensibilidade, grande especificidade para 0 elemento analisado, precisão de determinação boa ou muito boa, e assim por diante. Desde cedo, foram considerados como métodos de referência ou de arbitragem quando da compilação das concentrações recomendadas para os padrões internacionais (por exemplo, Stevens e outros 1960). Entretanto, por serem métodos que exigem manuseio às vezes complexo, bem como equipamentos e periféricos numa faixa de preços bastante altos, foram adotados por poucos laboratórios como métodos de rotina para a determinação dos elementos.

\subsection{Métodos analíticos especiais}

4.3.1 Fluorescência da scheelita sob ondas ultra-violetas de comprimento de onda curta

No Estado do Rio Grande do Norte, encontram-se as maiores jazidas de tungstênio, na forma da scheelita, no Brasil. A concorrência dos depósitos chineses colocou as minas ativas em situação operacional precária. Ao longo do final dos anos 70 e do início dos anos 80, a Companhia de Desenvolvimento de Recursos Minerais (estadual) executou um programa de avaliação de recursos existentes e prospecção para recursos novos.

O método analítico empregado inicialmente, quando testado contra padrões de teores de $\mathrm{W}$ conhecidos, revelou-se deficiente, a despeito de possuir a rapidez necessária para a determinação de grandes quantidades de amostras num prazo curto. A absorção de tungstênio por sílica gelatinosa, gerada durante o ataque da amostra, resultava em valores inferiores aos recomendados. Assim, procurou-se um método alternativo para uso no programa de prospecção.

O método de contagem de pintas de ouro em concentrados de minerais pesados, obtidos por bateiamento, já tinha se mostrado eficiente e rápido em etapas preliminares de prospeç̧ão para Au por técnicos da DOCEGEO. Resolveu-se, então, adaptar este método para a prospeç̧ão da scheelita. Este mineral possui uma fluorescência característica que é ativada por raios ultra-violetas de comprimento de onda curta, porém, não é ativada pelas ondas UV de comprimento longo. A scheelita 
da província norteriograndense contém, de um modo geral, uma baixa concentração de powellita (molibdato de cálcio) em solução sólida, o que confere à fluorescência uma tonalidade de branco levemente amarelada. Junto à falta de ativação da fluorescência da scheelita pelas ondas UV curtas, esta propriedade é suficiente para não haver confusão com outros minerais fluorescentes que ocorrem na região.

A contagem de pontos fluorescentes foi feita sobre uma aliquota de aproximadamente $10 \mathrm{~g}$ retirada do concentrado total de bateia previamente pesado. $\mathrm{A}$ fração da amostra representada pela alíquota, portanto, era conhecida.. Espalhou-se a alíquota uniformamente sobre uma placa de Petri. Realizou-se a contagem de pontos fluorescentes numa câmara escura, primeiro, em ondas UV longas (o que corresponde à medição do branco em outros métodos ópticos) e, depois, em ondas UV curtas. O valor obtido foi corrigido posteriormente pela fração do concentrado relativo ao peso total da amostra original.

\subsubsection{Catodoluminescência}

O candidato foi apresentado ao método de catodoluminescência (CL) pelo Geol. B. Riffel da CBMM durante pesquisa sobre aspectos dos carbonatitos de Angola. Subsequentemente, o usou numa pesquisa sobre minerais em granitóides brasilianos nordestinos, cujos resultados foram reportados em McReath et al., (1993). Nessa fase, verificou-se a possibilidade de aplicar o método ao estudo de zircões usados em geocronologia pelo método $\mathrm{U} / \mathrm{Pb}$, uma vez que o catodoluminescência ativada pelos elementos terras raras é muito sensivel, pois as concentrações desses elementos necessárias para a excitação da $\mathrm{CL}$ são bastante baixas, e a cor da $\mathrm{CL}$ é caracteristicamente bastante clara. Assim, é possível investigar a zonação das ETR, que traz informações sobre a história de cristalização ou reação do zircão. Após a caracterização com luz normal, transmitida e refletida, a utilização da $\mathrm{CL}$ junto à determinação da distribuição do háfnio pelo microscópio eletrônico ou pela microssonda eletrônica representa poderosa ferramenta na investigação da natureza dos zircões.

Atualmente, o autor é responsável pela implantação do Laboraótio de $\mathrm{CL}$ do IGc-USP, que conta com equipamentos para a captação de imagens de $\mathrm{CL}$, e para a medição dos espectros emitidos pelos mnerais presentes, para auxiliar na identificação dos elementos responsáveis para a ativação da $\mathrm{CL}$. 


\subsection{REFERÊNCIAS BIBLIOGRÁFICAS}

FAIRBURN, H.W. et al., 1951. A cooperative investigation of precision and accuracy in chemical, spectrochemical and modal analysis of silicate rocks. U. S. Geol. Surv., Buh. 980, pp 1-71

FLANAGAN,.F. J., 1969. US Geoogical Survey standards - II. First compilation of data for the new U. S. G. S. Rocks. Geochim. Cosmochim. Acta, 33: 81-120

GLADNEY, R. S.; JONES, E. A.; NICHOLL, E J. \& ROELANDTS, I., 1990. 1988 compilation of elemental concentration data for USGS basalt BCR-1. Geosyand. Newsl., 14: 209-359

GLADNEY, R. S.; JONES, E. A.; NICHOLL, E J. \& ROELANDTS, I., 1992. 1988 compilation of elemental concentration data for U. S. G. S. AGV-1, GSP-1 and G2. Geostand. Mewsl., 14: 111-300

GOVINDARAJU, K., 1994. 1994 compilation of working values and sample descriptions for 383 geostandards. Geostand. Newsl., 18: 1-158

McREATH, I., 1972. Petrogenesis in island arcs. Tese inédita de Doutorado, Universidade de Leeds, Inglaterra. $110 \mathrm{pp}$.

MCREATH, I.; RIFFEL, B. F. \& ALMEIDA, A. R. de, 1993. Estudos de minerais acessórios no granito de Quixadá - Quixeramobim por catodoluminescência e SEM/EDS. In: XV Simp. Geol. Nordeste, Natal. Bol. 13 (Resumos), p.3 373

NOCKOLDS, S. R. \& ALLEN, R., 1953. The geochemistry of some igneous rock series. Geochim. Cosmochim. Acta., 4: 105-142

STEVENS, R. E. et al., 1960. Second report on a cooperative investigation of the composition of two silicate rocks. U. S. Geol. Surv., Bull. 1113, p. 1-126 